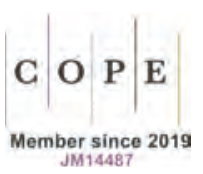

\title{
PHENOMENOLOGICAL RESEARCH ON GUEST COUCHSURFING EXPERIENCE
}

\author{
Halil İbrahim Karakanª (D), Kemal Birdirb (D), Aliye Akinc (D), Adnan Akin \\ a Independent researcher; http://orcid.org/0000-0003-3335-0923; e-mail: hikarakan@gmail.com \\ ${ }^{\mathrm{b}}$ Mersin University, Tourism Faculty; https://orcid.org/0000-0003-1353-3618; e-mail: kemalbirdir@mersin.edu.tr \\ c Bolu Abant İzzet Baysal University, Tourism Faculty; https://orcid.org/0000-0001-8589-7547; e-mail: aliye.akin@ibu.edu.tr \\ d Bolu Abant İzzet Baysal University, Bolu Vocational School; https://orcid.org/0000-0002-7023-1678; e-mail: adnan.akin@ibu.edu.tr
}

How to cite (APA style): Karakan, H.i.., Birdir, K., Akin, A., Akin, A. (2021). Phenomenological research on guest couchsurfing experience. Turyzm/Tourism, 31 (2), 39-63. https://doi.org/10.18778/0867-5856.31.2.03

\begin{abstract}
Couchsurfing (CS) is now regarded as an alternative platform that reflects changes in tourist accommodation preferences. The CS platform, based on the sharing economy, offers an opportunity to give various tourist experiences to travelers, as well as accommodation. This study aims to provide information about the travel motivations, prejudices, risk perceptions and experiences of CS guests. It has original value for the relevant literature, as it delves deeply into CS guests using a phenomenological approach. The present results show that the desire to sightsee new places, meet new people and recognize different cultures has motivated the participants. The study found that although most of the participants did not have prejudices or risk perceptions, CS first timers did. It has also been observed that participants are highly satisfied with their CS experiences and intend to take part in CS activities again.
\end{abstract}

\section{KEYWORDS}

couchsurfing, tourism, accommodation, travel, sharing economy

\section{ARTICLE INFORMATION DETAILS}

Received:

3 April 2021

Accepted:

15 September 2021

Published:

3 December 2021

\section{INTRODUCTION}

Internet usage is increasing rapidly across the world as communication technology evolves and becomes widespread. Emerging technologies may help select messages, people and groups, thus establishing communication (İmre, 2020). Therefore, a communication network with a large memory capacity far beyond the human brain has been built on a global scale. Social media tools, online platforms where people with common interests share their feelings and thoughts, are growing rapidly parallel with these advances (Weber, 2009). The Digital 2020: Global digital overview report shows that $59 \%$ (approximately 4.54 billion) of the world's population have already used the internet. In addition to this, $92 \%$ (4.18 billion) of internet users around the world are also mobile internet users, furthermore, the same report reveals that $49 \%$ (about 3.80 billion) are active social media users (We are social, 2020).

Social media are Web 2.0-based sites that bring people together on a virtual platform, provide deeper social interaction through a stronger community, and allow for the implementation of collaboration projects (Brown, 2009). Therefore, social media, which also provides membership and content creation at user level while offering social interaction and online services, has become an integral part of our daily lives (Başarangil, 2019). Thanks to this feature, social media have attained a place in various sectors, especially the service industry (Aktan, 2018). It also plays an important role in the laborintensive tourism tourism sector and gives particular importance to human relations in terms of sharing tourist experiences while allowing all stakeholders involved in tourism to grow (Huang, Goo, Nam, Yoo, 
2017). Tourists use various social media tools extensively to decide their destination preferences (Xiang, Gretzel, 2010) and this has become even more important for tourist satisfaction and development as well (Anderson, 2012). The development of social media-oriented platforms and the increase in the number of people using them especially reshape the relationship and communication of tourists with each other and with tourism managers.

Social media platforms allow travelers to share their travel experiences quickly and conveniently. Posts shared on such platforms have become an important source of information that can influence the travel decisions of potential visitors. One of these platforms is couchsurfing (CS) (Kang, Schuett, 2013). CS may be expressed as a platform that reflects a new trend in tourists' demand for accommodation in the tourism sector. Accordingly, CS is a platform that offers free lodging to those traveling on a global scale.

\section{COUCHSURFING}

CS, a not-for-profit sharing economy platform where money is not used as a means of exchanging services, is a worldwide network created to make connections between travelers and the local communities visited (Lauterbach, Truong, Shah, Adamic, 2009). CS serves travelers, especially in their choice of accommodation. It is an organization that has many functions such as gathering users from different destinations together, allowing them to establish relationships and giving information about destinations (Chung, Buhalis, 2009).

The idea for CS was conceived by Casey Fenton during a trip to Iceland in 1999. Fenton sent e-mails containing lodging requests to university students studying in Reykjavik to find cheap lodging (Molz, 2011). Fenton received more than 50 invitations in reply to his e-mails. After returning to the USA, he wanted to share his experiences. For this purpose, in 2004, he created a website and that is how Couchsurfing came to life - a hospitality network that brings travelers around the world together with existing hosts (Rosen, Lafontaine, Hendrickson, 2011).

Being a member of the CS network requires verification and reference. Members confirm their identity and addresses for a nominal fee and this is important to win other users' trust. References are the ratings and feedback that members leave on others' profiles. A member who has gained CS experience and is now called a couchsurfer should carry out an assessment, positive, neutral (undecided) or negative, after the visit (Lauterbach, Truong, Shah, Adamic, 2009). After these processes are completed, members may seek hosts in specific destinations, send lodging requests, join active member discussion groups on common interests through the CS platform. The typical CS process is to list potential hosts at their destination and contact them requesting a stay. In this way both hosts and guests review each other's profiles to find information. As plans become clearer, hosts and guests are quite likely to share contact information such as email addresses and phone numbers and accept the lodging offers (Molz, 2011). In addition, hosts not only share their own homes, but also their free time and other resources with guests (Bialski, 2012).

"Share your life and culture, create connection, offer kindness, stay curious and leave it better than you found it" are the core values of CS platforms. For this reason, the platform may offer users a meaningful and alternative travel route that includes emotions, feelings, experiences and personal characteristics, in addition to 'complimentary' lodging. It also offers advantages such as cultural and social interaction, self-knowledge and social responsibility (Zgolli, Zaiem, 2018).

Today, CS has become a global community consisting of 14 million people sharing their lives, worlds and journeys in more than 200,000 destinations in nearly 180 countries (Couchsurfing, 2021). The average age of couchsurfers is 28 and CS is most popular among young people aged 18 to $34,37.9 \%$ of the total. People over 50 make up about 2\% (Hanchuk, Bondarenko, Varfolomyeyeva, Pakhomova, Lohvynenko, 2020).

Therefore, it can be said that participation in the social network is more common among the young and middle aged, covering the period of those born in the 1980s and 1990s, known as Generation Y. It is well known that those born in the late 1990s, whose lifestyles and ideas are considered to be different from older people, depend more on technology, the internet and social media. Indeed, it can be said that a generation that needs constant interaction with each other via these communication channels has emerged (Doyle, 2016). Accordingly, Generation Y users who have a vacation experience via the CS platform generally do not enjoy ordinary tourism activities; preferring to gain new and different experiences that include the sharing of values. Therefore, it is possible to state that the CS platform increases tourism-related mobility and puts a different complexion on the tourism and travel industry.

\section{LITERATURE REVIEW}

CS is a platform that enables travelers around the world to gather together and interact culturally and socially. Due to this, CS has become a subject investigated by many academics from different disciplines and there are many national and international studies covering the CS platform. It appears that CS academic studies 
focus mainly on its users as host and guest. In this context, some studies of CS include the socio-culturaleconomic and demographic characteristics of the platform members, their reasons for being one, the way they use the platform, the way profiles are created, profile content and effects, how the mutual trust mechanism works, and the importance of the reference system in terms of sharing culture. In addition, there are important studies evaluating the mutual relations established and experiences gained via the CS platform in the context of tourism.

Chen (2018) studied the online and offline performance of CS participants, including some hidden inappropriate actions, and aimed to uncover the reasons that have transformed the CS platform from a simple hospitality exchange network to a specific travel style. This study revealed that participants have now started to prefer holidays within the scope of guest exchange, as this platform offers participants the opportunity for cultural interaction and creates a mutually friendly and tolerant vacation environment. Spitz (2017) tested the cross-cultural interaction levels of Turks according to different cultural theories in terms of CS experiences. The study found that the platform renders cross-cultural comparisons possible and provides a cosmopolitan desire for cultural exchange in terms of openness and difference. Spitz (2017) indicated that in return for hospitality, social and cultural capital has become an element exchanged through this social network. In their work "CouchSurfing cosmopolitanisms: Can tourism make a better world?", Picard and Buchberger (2013) focus on comparing modern and post-modern tourism. They indicated that CS helps both local people and tourists to escape the package tours of modern tourism and that socio-cultural convergence may open doors to a more habitable world. They also stated that direct and deep relationships were forged between hosts and guests through hospitality platforms without any controlling mechanism, thus changing tourism-related hospitality.

Moreira and Gomes (2018) examined hosts and guests registered on the CS platform in the Jaguarão municipality in the southernmost part of Rio Grande do Sul, Brazil. Their study aimed to identify and discuss the interests and motivations of hosts and guests on CS trips who were both asked to complete semi-structured questionnaires online and offline. Accordingly, the factors that orientate hosts and guests to CS are duty-free shopping, visiting relatives, developing professional interests and enjoying leisure time during holidays. Schuckert, Peters and Pilz (2017) interviewed 14 people in Austria using semi-structured questionnaires to determine the motivations of CS members for travelling and hosting. They found that members are generally involved in various social interactions with local people in order to get information about the area they have visited. In addition, they stated that the host-guest relationship gains experience of cultural exchange and authenticity. Ayers-Greenidge (2012) tried to determine the motivations and personality traits of Taiwanese CS members. The study found that participants had personality traits such as openness to experience, extraversion and conflict. The author also found that members had motivational elements including cultural interaction, self-realization, a quest for different experiences, curiosity and an interest in different lifestyles.

Dén-Nagy and Király (2014) carried out a study to demonstrate how CS works despite the potential risks and uncertainties, and how it has changed into an expanding and successful social platform. They embarked on an exploratory qualitative research project in Hungary in 2012-2013 which showed that the high level of trust among members increases motivation, leads to strong cultural interaction, that members have a low-risk perception, and that trust is built based on emotions. In her master's thesis titled "CS Experiences, reputation, references and decision-making in an online hospitality network", Franz (2013) analyzed the behavior patterns that emerged after a negative experience during hospitality by focusing on the CS platform and hospitality exchange. Franz conducted online interviews with 35 CS participants and found that users have worries about status and reputation as a result of negative experiences and references. She also found that users even avoided expressing positive sharing due to these worries.

Pultar, Raubal and Goulias (2012) determined the usage habits of members using the CS platform according to their demographic characteristics and geographical data; 228 participants from 40 different countries were asked to fill in a questionnaire. They found that older members using the platform lodge more than younger, and male users are more involved in CS as guests than female. Besides, they observed that individual members of the platform in economically underdeveloped areas such as Latin America and Asia mostly use it as a homeowner.

\section{Methodology}

The study aimed to determine the travel motivations, travel behaviors, risk perceptions, prejudices, satisfaction levels and re-participating intentions of participants who have experienced CS. The study also aims to provide suggestions to guide potential users based on the experiences of those using this platform.

An exploratory research design was used because a study of CS specific to guests has not been made using a phenomenological approach before. Exploratory research is described as a type of research carried out 
to collect preliminary information to help identify problems about which detailed information is not known and has yet to be found, and this can then be used to propose a hypothesis. It has been reported that it would be suitable to use qualitative methods in such studies (Okumuş, 2015) and data can be collected using an interview method.

In line with the main objectives of the study, answers to the following questions were sought:

1. What are the travel motivations of couchsurfer participants?

2. What are the risk perceptions and prejudices of those who travel as couchsurfers?

Although there are various studies on hosts in the CS system, there are an insufficient number specific to guests. We found no phenomenological research regarding guests in CS activities. This study has original value as it was made using a phenomenological approach from qualitative research methods. Phenomenology tries to reveal the most essential meaning. In such types of research, the opinions of those who have experience of the subject are taken, and these experiences are taken into account. Phenomenology is a method that handles experiences, thoughts and feelings correctly and impartially as these are the main source of information that individuals have (Güler, Halıcıoğlu, Taşğin, 2013). It is difficult to carry out phenomenological research, but extremely valuable information can be obtained in this way (Cope, 2003). In addition, as a result of a national and international literature search, no study was found in which different CS countries were included and as this study has been carried out on a sample of CS guests from 25 different nationalities, it is original and important.

The study sample consists of individuals participating in CS activities. In order to find participants, three CS participants were reached through the CS official platform and CS groups on social media platforms (Facebook and Instagram), and online interviews were held. Then, using the snowball sampling method, other participants were reached, and online interviews were conducted. The sample type was criterion sampling in which two criteria were considered: the first is that the participant had experienced CS activities as a guest, and the second is that the participant represents a country different from the others. By doing so, maximum diversity was provided and its purpose is to include cultural differences. As such, 25 CS participants from 25 different nations were included in the study.

A structured interview technique from qualitative approaches was used as the data collection method. Data was gathered between $10^{\text {th }}$ December 2020 and $5^{\text {th }}$ February 2021. The interview form consisted of six open-ended questions about CS experiences and six demographic questions.

The data collected from the participants via interviews were presented descriptively through a phenomenological method. In addition, the data from some questions were digitized and presented in tables while others were collected under themes with the help of content analysis. A word or tag cloud and network map were created using the Voyant Tools application. A word cloud is defined as a visual representation in which words found among the answers given by participants to open-ended questions are illustrated in a larger and more central position according to frequency level. While the algorithm of word cloud analysis positions centrally the most important words in the form of larger font sizes, it puts less important words into smaller ones (Voyant-tools, 2021).

\section{RESULTS}

Firstly, we present information about the demographic characteristics of the participants. Then, we include views on the travel motivations of participants having a CS experience, and on their risk perceptions, prejudices, problems encountered, satisfaction levels, intention to participate again, socialising level, travel behaviors and cultural interactions.

Table 1 presents the demographic characteristics of the participants: 25 different CS travelers from six continents and 25 countries were included in the study. Of the participants, 12 were male and 13 were female, seven were married and 18 were single. The participants consisted of individuals from various occupations and students. Their ages ranged from 22 to 44 years, which is young to middle aged, and 21 had at least a bachelor's degree.

Table 2 shows the travel behaviors of the participants, including daily expenses, items bought (product/ service), co-participants, number of CS trips and the average length of stays. These data suggest that $24 \%$ of participants spend no money during CS trips $(\mathrm{n}=6$; $3^{\text {rd }}$ rank); $36 \%$ spend up to $\$ 25$ per day $\left(n=9 ; 1^{\text {st }}\right)$; and $28 \%$ between $\$ 26$ and $\$ 50$ was $\left(n=7 ; 2^{\text {nd }}\right)$. When taking spending into account, participants paid no accommodation fee in accordance with the practice of couchsurfing. The largest item was food $(44 \% ; n=15)$ while others were gifts and other shopping $(21 \% ; n=7)$, and transportation $(15 \% ; n=5)$. Concerning co-participants, other couchsurfing members ranked first, with $25.93 \%(n=7)$. Others accompanying the participants were spouses $(22.22 \%$; $\mathrm{n}=6)$, close friends $(14.81 \% ; \mathrm{n}=4)$ and virtual friends $(11.11 \% ; n=3)$. The percentage alone was $18.52 \%(n=5)$. Considering frequency $80 \%$ of them had repeated CS traveling, for the remaining $20 \%$ it was the first time. The participants' lengths of stay were $20 \%(n=5)$ for only one night, followed by $14 \%(n=7)$ for $6-7$ days, $12 \%(n=6)$ for $4-5$, and $8 \%(n=4)$ for $2-3$. The number of participants staying more than a week was only $6 \%(n=3)$. 
Table 1. Participant demographic information

\begin{tabular}{|c|c|c|c|c|c|c|}
\hline Participants & Nationality & Occupation & Age & Marital Status & Sex & Education \\
\hline Couchsurfer 1 & Turkish & Officer & 27 & Single & Male & Graduate \\
\hline Couchsurfer 2 & Chinese & Photographer & 38 & Married & Female & Graduate \\
\hline Couchsurfer 3 & French & Student & 25 & Single & Female & Graduate \\
\hline Couchsurfer 4 & Japanese & Nurse & 32 & Single & Female & Graduate \\
\hline Couchsurfer 5 & Moroccan & Marketeer & 35 & Single & Female & Master's degree or more \\
\hline Couchsurfer 6 & American & Taxi driver & 29 & Single & Male & High school or less \\
\hline Couchsurfer 7 & Philippines & Housemaid & 34 & Single & Female & High school or less \\
\hline Couchsurfer 8 & Brazilian & Waitress & 36 & Single & Female & High school or less \\
\hline Couchsurfer 9 & Mexican & Hair stylist & 38 & Single & Female & Graduate \\
\hline Couchsurfer 10 & Pakistani & Junior doctor & 24 & Single & Male & Graduate \\
\hline Couchsurfer 11 & Italian & Secretary & 41 & Single & Male & Graduate \\
\hline Couchsurfer 12 & Greek & Security officer & 31 & Married & Male & Graduate \\
\hline Couchsurfer 13 & China & $\begin{array}{l}\text { PhD student } \\
\text { in tourism }\end{array}$ & 42 & Single & Male & Master's degree or more \\
\hline Couchsurfer 14 & Egyptian & Student & 22 & Single & Male & Graduate \\
\hline Couchsurfer 15 & Cypriot (Greek) & Lecturer & 44 & Single & Male & Master's degree or more \\
\hline Couchsurfer 16 & Azerbaijani & Developer & 28 & Single & Male & High school or less \\
\hline Couchsurfer 17 & Canadian & Building manager & 39 & Single & Male & Graduate \\
\hline Couchsurfer 18 & Spanish & Architect & 35 & Married & Female & Graduate \\
\hline Couchsurfer 19 & British & Computer engineer & 28 & Single & Female & Graduate \\
\hline Couchsurfer 20 & Norwegian & Musician & 27 & Married & Male & Graduate \\
\hline Couchsurfer 21 & German & Sociologist & 42 & Married & Female & Graduate \\
\hline Couchsurfer 22 & Israeli & Translator & 24 & Married & Male & Graduate \\
\hline Couchsurfer 23 & Russian & Teacher & 33 & Single & Female & Graduate \\
\hline Couchsurfer 24 & Australian & Tour Guide & 42 & Single & Female & Master's degree or more \\
\hline Couchsurfer 25 & Iranian & Student & 23 & Married & Female & Graduate \\
\hline
\end{tabular}

Source: authors.

Table 2. Travel behavior of participants

\begin{tabular}{|c|c|c|c|c|c|c|c|c|}
\hline \multirow{3}{*}{$\begin{array}{l}\text { Expenditure } \\
\text { per day }\end{array}$} & \multicolumn{2}{|r|}{ None } & $1-25 \$$ & $26-50 \$$ & $51-75 \$$ & $76-100 \$$ & More than 100 \$ & Total \\
\hline & $\mathrm{N}$ & 6 & 9 & 7 & 1 & 1 & 1 & 25 \\
\hline & $\%$ & 24 & 36 & 28 & 4 & 4 & 4 & 100 \\
\hline \multirow{3}{*}{$\begin{array}{l}\text { Expenditure } \\
\text { items }\end{array}$} & \multicolumn{2}{|r|}{ Food } & Transport & $\begin{array}{c}\text { Gifts } \\
\text { and other shopping }\end{array}$ & Accommodation & None & Event fees & Total \\
\hline & $\mathrm{N}$ & 15 & 5 & 7 & 0 & 6 & 1 & 34 \\
\hline & $\%$ & 44 & 15 & 21 & 0 & 18 & 3 & 100 \\
\hline \multirow{3}{*}{ Co-participants } & \multicolumn{2}{|r|}{$\begin{array}{c}\text { Other } \\
\text { couchsurfers }\end{array}$} & Close friends & Family members & Spouse & $\begin{array}{l}\text { Virtual } \\
\text { friends }\end{array}$ & Alone & Total \\
\hline & $\mathrm{N}$ & 7 & 4 & 2 & 6 & 3 & 5 & 27 \\
\hline & $\%$ & 25.93 & 14.81 & 7.41 & 22.22 & 11.11 & 18.52 & 100 \\
\hline \multirow{3}{*}{$\begin{array}{l}\text { Number of CS } \\
\text { trips }\end{array}$} & \multicolumn{2}{|r|}{ Once } & Twice & Three times & Four times & 5-10 times & $\begin{array}{c}\text { More than } \\
10 \text { times }\end{array}$ & Total \\
\hline & $\mathrm{N}$ & 5 & 3 & 2 & 2 & 2 & 11 & 25 \\
\hline & $\%$ & 20 & 12 & 8 & 8 & 8 & 44 & 100 \\
\hline \multirow{3}{*}{$\begin{array}{l}\text { Average length } \\
\text { of stay }\end{array}$} & \multicolumn{2}{|r|}{ One night } & $\begin{array}{l}\text { Two-three } \\
\text { nights }\end{array}$ & Four-five nights & Six-seven nights & $\begin{array}{l}\text { More than } \\
\text { a week }\end{array}$ & $\begin{array}{l}\text { More than } \\
\text { two weeks }\end{array}$ & Total \\
\hline & $\mathrm{N}$ & 5 & 4 & 6 & 7 & 2 & 1 & 25 \\
\hline & $\%$ & 20 & 8 & 12 & 14 & 4 & 2 & 100 \\
\hline
\end{tabular}

Source: authors. 
It was observed that although CS travelers had various tourism expenses such as food, souvenirs and shopping, there were those who while not spending on accommodation, generally participated in activities with other CS members, with their spouses or alone, stayed for one day or up to a week, and repeated CS traveling.

Table 3 includes information about participants' opinions on CS travel experiences: satisfaction with the host's hospitality, satisfaction with CS trips, the contribution of CS to socialising and their intention to participate again.

Considering satisfaction levels according to the hospitality of the hosts, almost all participants $(96 \%, \mathrm{n}=24)$ were satisfied, with $88 \%(n=22)$ having high levels of satisfaction. One participant was undecided. $92 \%$ ( $n=23$ ) were highly satisfied with CS trips, while one was unsure and one dissatisfied. 92\% $(\mathrm{n}=23)$ thought that CS trips contributed highly to socialising while two thought that they did not. Furthermore most participants had an intention to CS again: $96 \%(n=24)$, including $88 \%(n=22)$ at a high level. One person $(4 \%)$ was undecided. Therefore, the CS travelers participating in the research were highly satisfied with the hospitality and CS trips, and intended to participate again. In addition, they considered that CS trips contributed to socialising at a high level.

The phenomenological codings for participants' motivation for CS travel are given in Table 4. These codings are briefly identified as participating in hobbies and spiritual activities, socializing, cultural interaction and sightseeing new places, leaving memories, having adventures and new experience, learning a language, safe tourism, free or cheap holiday, making CS friends, new food tastes, free and comfortable accommodation, experiencing common feelings, shopping and home accommodation.
Among factors that motivate CS trips, "meeting new people and socializing", "recognizing new cultures through cultural interaction" and "traveling to new destinations" ranked first, with a $21.55 \%$ each $(n=25)$. All of the participants identified these. Some participants' views are as follows.

CS2: "I am a photographer traveling and taking photos of different places in the world, collecting memories attracts me and CS is nice way to do it. I also really love the adventure and seeing new cities, countries, people, cultures! It's very enjoyable to meet surfers traveling across countries to share good moments and language practice. It's free! and safer than hotel I think".

CS8: "It is better than renting a room in a hotel, I feel safer and more relaxed when I'm with couchsurfers. To meet new people who also love traveling allows me to find myself. Visit new countries to socialize, save money, and find similar spirits".

CS14: "I always wanted to have friends from other nationalities and travel all over the world, so CS gives that to me. To meet more people, make friends, awesome experiences, getting to know different cultures, trying different types of food. I like to travel around the world but sometimes it can be expensive, so CS is nice idea to reduce expenses and to save money".

CS19: “It's a most easy way of joining another culture. The common feeling inside CS attracts me most. The interaction with locals, and exchange of culture, knowledge and experiences. That's a different way of travelling and it feels good having friends from different nationalities".

CS21: "For me seeing a new country and meeting a friend that I hadn't seen in real life. Meeting people and seeking discomfort. Interaction with those from other cultures. Experiencing different culture when I was with my CS friend and it's free to stay in his house, you know, houses are always better than hotels. Traveling and seeing new things. I love traveling and it's an amazing experience to have a nice time, to find new friends".

Table 3. Participants' opinions on their experiences

\begin{tabular}{|c|c|c|c|c|c|c|c|}
\hline & \multicolumn{3}{|c|}{ Satisfied } & Not sure & \multicolumn{3}{|c|}{ Unsatisfied } \\
\hline \multirow{3}{*}{$\begin{array}{l}\text { Satisfaction } \\
\text { with hosting }\end{array}$} & \multicolumn{2}{|c|}{ Absolutely satisfied } & Satisfied & Not sure & Unsatisfied & Absolutely unsatisfied & Total \\
\hline & $\mathrm{N}$ & 22 & 2 & 1 & 0 & 0 & 25 \\
\hline & $\%$ & 88 & 8 & 4 & 0 & 0 & 100 \\
\hline \multirow{3}{*}{$\begin{array}{l}\text { Satisfaction } \\
\text { with CS }\end{array}$} & \multicolumn{2}{|c|}{ Absolutely satisfied } & Satisfied & Not sure & Unsatisfied & Absolutely unsatisfied & Total \\
\hline & $\mathrm{N}$ & 23 & 0 & 1 & 1 & 0 & 25 \\
\hline & $\%$ & 92 & 0 & 4 & 4 & 0 & 100 \\
\hline \multirow{3}{*}{$\begin{array}{l}\text { CS contribution } \\
\text { to socialising }\end{array}$} & \multicolumn{2}{|c|}{ Absolutely yes } & Yes & Not sure & No & Absolutely no & Total \\
\hline & $\mathrm{N}$ & 23 & 0 & 0 & 2 & 0 & 25 \\
\hline & $\%$ & 92 & 0 & 0 & 8 & 0 & 100 \\
\hline \multirow{3}{*}{$\begin{array}{l}\text { Intention } \\
\text { to CS again }\end{array}$} & \multicolumn{2}{|c|}{ Absolutely yes } & Yes & Not sure & No & Absolutely no & Total \\
\hline & $\mathrm{N}$ & 23 & 1 & 1 & 0 & 0 & 25 \\
\hline & $\%$ & 88 & 8 & 4 & 0 & 0 & 100 \\
\hline
\end{tabular}

Source: authors. 
Table 4. Phenomenological codings regarding factors motivating participants on CS trips

\begin{tabular}{|c|c|c|c|c|c|c|c|c|c|c|c|c|c|c|c|c|c|c|c|c|c|c|c|c|c|c|c|}
\hline$\frac{\mathscr{n}}{8}$ & $a^{\circ}$ & Z & $\bar{y}$ & นู & లூ & फु & Un & นึ & $\hat{\nu}$ & $\infty$ & ठै & $\begin{array}{l}0 \\
\text { Uू }\end{array}$ & $\overline{\vec{y}}$ & ปี & $\frac{n}{\tilde{U}}$ & मु & 足 & $\frac{0}{\tilde{n}}$ & $\vec{y}$ & $\frac{\infty}{\tilde{y}}$ & $\frac{\vartheta}{\tilde{y}}$ & $\begin{array}{l}\text { సे } \\
\text { లె }\end{array}$ & స్ & $\begin{array}{l}\text { สิ } \\
\text { ป }\end{array}$ & $\begin{array}{l}\text { న } \\
\text { లు }\end{array}$ & స્心 & $\begin{array}{l}\text { Na } \\
\text { U }\end{array}$ \\
\hline $\begin{array}{l}\text { Hobby, spiritual, } \\
\text { recovery, recreation }\end{array}$ & 2.59 & 3 & & $x$ & & & & & & $x$ & & & & & & & & & & & & & $x$ & & & & \\
\hline New people, socializing & 21.55 & 25 & $\mathrm{x}$ & $x$ & $x$ & $x$ & $x$ & $x$ & $x$ & $x$ & $x$ & $x$ & $\mathrm{x}$ & $\mathrm{x}$ & $x$ & $\mathrm{x}$ & $\mathrm{x}$ & $\mathrm{x}$ & $x$ & $\mathrm{x}$ & $\mathrm{x}$ & $\mathrm{x}$ & $\mathrm{x}$ & $\mathrm{x}$ & $x$ & $\mathrm{x}$ & $\mathrm{x}$ \\
\hline $\begin{array}{l}\text { Meeting new cultures } \\
\text { and cultural interaction }\end{array}$ & 21.55 & 25 & $\mathrm{x}$ & $\mathrm{x}$ & $\mathrm{x}$ & $\mathrm{x}$ & $\mathrm{x}$ & $x$ & $x$ & $x$ & $x$ & $x$ & $x$ & $x$ & $x$ & $x$ & $x$ & $x$ & $x$ & $x$ & $x$ & $x$ & $x$ & $x$ & $x$ & $x$ & $x$ \\
\hline $\begin{array}{l}\text { To travel } \\
\text { to new destinations, } \\
\text { cities or countries }\end{array}$ & 21.55 & 25 & $\mathrm{x}$ & $x$ & $x$ & $x$ & $x$ & $x$ & $x$ & $x$ & $x$ & $x$ & $x$ & $x$ & $x$ & $x$ & $x$ & $x$ & $x$ & $x$ & $x$ & $x$ & $x$ & $x$ & $x$ & $x$ & $x$ \\
\hline $\begin{array}{l}\text { To have good moments } \\
\text { and memories }\end{array}$ & 3.45 & 4 & & $x$ & & & & $x$ & & & & & & & & & $x$ & & & & & & & $x$ & & & \\
\hline $\begin{array}{l}\text { To have adventures } \\
\text { and new experiences }\end{array}$ & 5.17 & 6 & & $x$ & & & $x$ & & & $x$ & & & & & & $x$ & & & & & $x$ & & $x$ & & & & \\
\hline $\begin{array}{l}\text { To practice language } \\
\& \text { learning new ones }\end{array}$ & 2.59 & 3 & & $x$ & & & & & & & & & & & & & & & & & & & & $x$ & & & $x$ \\
\hline Safe tourism & 2.59 & 3 & & $x$ & & & & & & $x$ & & & & & & & & & & & $x$ & & & & & & \\
\hline $\begin{array}{l}\text { Free or cheap holiday, } \\
\text { saving money }\end{array}$ & 2.59 & 3 & & $x$ & & & & & & $x$ & & & & & & $x$ & & & & & & & & & & & \\
\hline To meet CS friends & 5.17 & 6 & & $x$ & & $x$ & & & & $x$ & & & & & & $x$ & & & & & $x$ & & $x$ & & & & \\
\hline New food tastes & 1.72 & 2 & & & & & & & & & & & & & $x$ & & & & & & & & & & & & $x$ \\
\hline $\begin{array}{l}\text { Free and comfortable } \\
\text { accommodation }\end{array}$ & 2.59 & 3 & & $x$ & & & & & & $x$ & & & & & & & & & & & & & $x$ & & & & \\
\hline $\begin{array}{l}\text { Experiencing common } \\
\text { feelings }\end{array}$ & 2.59 & 3 & & & & & & & & $x$ & & & & & & & & & & & $x$ & & & & & $x$ & \\
\hline Shopping and gifts & 1.72 & 2 & & & & $x$ & & & & & & & & & & & & & & & $\mathrm{x}$ & & & & & & \\
\hline Home accommodation & 2.59 & 3 & & $x$ & & & & & & $x$ & & & & & & & & & & & & & $\mathrm{x}$ & & & & \\
\hline
\end{tabular}

Source: authors.

Table 5 gives phenomenological codings for the prejudices and risk perceptions of the participants on CS trips. These codes are related to the themes of not perceiving risk, prejudice and of problem experiences. $60 \%$ of the participants ( $n=15 ; 1^{\text {st }}$ rank) had no perception of risk or prejudice before CS traveling. Those who did have before their first CS experiences but did not have any problems during the trip was $20 \%(n=5)$. The percentage of CS participants who experienced some problems was $20 \%(n=5)$ : three experienced "exposure to hygiene problems" with one each for "exposure to sexual harassment" and "exposure to theft".
Although most did not have prejudices and risk perceptions, $40 \%(n=10)$ felt some concerns. However, half of those with prejudices or risk perceptions seemed to have been right in their concerns. The views of some CS participants who were prejudiced before their first experience but did not encounter any problem are as follows.

CS5: "At first I was afraid but after I got used to it, I knew how to handle it and I was not sure how or if it worked until I joined. It's a safe platform for me for so many years".

CS8: “New people and new places couldn't be trusted. I always do my CS with the same person, and I have CS experiences, so I have not been perceiving any risk".

Table 5. Phenomenological codings for participants' prejudices about CS and perceptions of risk

\begin{tabular}{|c|c|c|}
\hline Codes & $\mathrm{N}$ & $\%$ \\
\hline I have never had any perception of risk or prejudice & 15 & 60 \\
\hline I have never experienced any problem, but I had prejudices / perceived risk before my first CS experience & 5 & 20 \\
\hline I experienced problems: & 5 & 20 \\
\hline I experienced hygiene problems & 3 & 12 \\
\hline I was exposed to sexual harassment & 1 & 4 \\
\hline I was exposed to theft & 1 & 4 \\
\hline Total & 25 & 100 \\
\hline
\end{tabular}

Source: authors. 
CS14: "I didn't get any risk, but you when know new place, new culture and you are the new blood... it was risk in the first experience. I prefer to go with a person that I know so I don't have any bad ideas about it anymore".

CS17: “I didn't experience a risk, but I perceived some risk in my first experience like that".

CS21: "I could have an accident and my family may not know where to find me and I was little nervous walking in the streets at night in a new, distant, and foreign city".

CS23: "Before my first CS I was little bit afraid because I hadn't met those people in real life".

CS24: "Yeah, because that person was my very good friend but like I said I only knew him from social media apps. everyone was prejudiced about it but after I got used to it, I didn't get any prejudice".

Some of the participants were faced with problems such as hygiene, sexual harassment and theft. Views of some participants in this respect are as below:

\section{Hygiene risk:}

CS6: “Little bit hygiene I don't want to judge people with their hygiene culture but for me the place that I stay wasn't clean enough for me".

CS9: "Yes home we stayed - it was not hygienic".

CS11: "Not really, just safety and hygiene issues".

\section{Sexual harassment risk:}

CS5: "I think that sometimes guys think that CS is the new tinder".

CS7: "Yeah, especially some guys can be perverted even how they look at you its kind a sexual harassment".

CS8: "Yes a little guy sometimes is trying to force me to drink and one day one guy on our couch surfing app did sexual things that I can even say it was very weird, but nothing bad happened because I walk away".

CS9: "Yes as a woman we take risk with creepy and traumatized people can be weird and dangerous sometimes".

Table 6. Phenomenological codings on participants' views on CS cultural interaction, cultural tourism and socialising

\begin{tabular}{|c|c|c|c|c|c|c|c|c|c|c|c|c|c|c|c|c|c|c|c|c|c|c|c|c|c|c|c|}
\hline$\frac{0}{0}$ & Z & $\partial^{\circ}$ & $\tilde{u}$ & Uै & $\tilde{n}^{\infty}$ & ש் & un & U & un & $\begin{array}{l}\infty \\
\cup \\
\cup\end{array}$ & à & $\begin{array}{l}0 \\
\tilde{n} \\
u\end{array}$ & $\vec{y}$ & $\stackrel{\sim}{\tilde{U}}$ & $\frac{m}{\tilde{D}}$ & $\begin{array}{l}\forall \\
\tilde{U} \\
u\end{array}$ & $\begin{array}{l}n \\
\omega \\
u \\
u\end{array}$ & $\begin{array}{l}0 \\
\tilde{n} \\
u\end{array}$ & $\begin{array}{l}\tilde{u} \\
\tilde{u}\end{array}$ & $\begin{array}{l}\infty \\
\vec{v} \\
\cup\end{array}$ & $\frac{a}{\tilde{v}}$ & 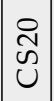 & 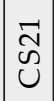 & $\begin{array}{l}\widetilde{N} \\
\text { U }\end{array}$ & $\begin{array}{l}\tilde{N} \\
\tilde{U}\end{array}$ & $\begin{array}{l}\mathbb{N} \\
\text { U }\end{array}$ & 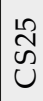 \\
\hline $\begin{array}{l}\text { Learning } \\
\text { new cultures } \\
\text { and cultural synthesis }\end{array}$ & 13 & 13.13 & $\mathrm{x}$ & $x$ & $x$ & & $x$ & & & $x$ & & $x$ & & $\mathrm{x}$ & $x$ & & & $x$ & & $\mathrm{x}$ & & $x$ & $x$ & & $\mathrm{x}$ & & \\
\hline $\begin{array}{l}\text { Having friends from } \\
\text { new cultures }\end{array}$ & 12 & 12.12 & $x$ & & $x$ & $\mathrm{x}$ & & & $x$ & & $x$ & & $x$ & & $x$ & & $x$ & & $x$ & & & $x$ & & $x$ & & $x$ & \\
\hline $\begin{array}{l}\text { Meeting new people } \\
\text { in different culture }\end{array}$ & 10 & 10.10 & $\mathrm{x}$ & $x$ & & & & $x$ & $x$ & & & $x$ & & $x$ & & $x$ & & $x$ & & & $x$ & & $x$ & & & & \\
\hline Find out new things & 5 & 5.05 & & & $x$ & & & & & $x$ & $x$ & & & & & & $x$ & & & & & & & & & & $x$ \\
\hline $\begin{array}{l}\text { Broadening horizons } \\
\& \text { to open minds }\end{array}$ & 14 & 14.14 & $x$ & $x$ & $x$ & & $x$ & $x$ & & $x$ & & & $x$ & & & $x$ & & & $x$ & & $x$ & & $x$ & $x$ & & $x$ & $x$ \\
\hline $\begin{array}{l}\text { New experiences } \\
\text { (food, travel, } \\
\text { sightseeing) }\end{array}$ & 8 & 8.08 & $\mathrm{x}$ & $x$ & $\mathrm{x}$ & & & & $x$ & & $x$ & & & & $x$ & & & & & $x$ & & & & & & & $x$ \\
\hline $\begin{array}{l}\text { Experiencing } \\
\text { the destination } \\
\text { culture in its natural } \\
\text { environment }\end{array}$ & 5 & 5.05 & & $x$ & & & & & & & & $x$ & & & & & & $x$ & & & & & & & $\mathrm{x}$ & $x$ & \\
\hline $\begin{array}{l}\text { Learning a different } \\
\text { language }\end{array}$ & 5 & 5.05 & & & $x$ & & $x$ & & & & & & & $x$ & & & & & & & $x$ & & & $x$ & & & \\
\hline $\begin{array}{l}\text { Make dreams } \\
\text { come true }\end{array}$ & 6 & 6.06 & & & $x$ & & & $x$ & & & & & $x$ & & & & $x$ & & $x$ & & & $x$ & & & & & \\
\hline $\begin{array}{l}\text { To contribute } \\
\text { to cultural tourism }\end{array}$ & 5 & 5.05 & & & $x$ & & & & $x$ & & & $x$ & & & & $x$ & & & & & $x$ & & & & & & \\
\hline $\begin{array}{l}\text { Learning } \\
\text { to be anti-racist, } \\
\text { tolerant, helpful, } \\
\text { peaceful } \\
\text { and hospitality }\end{array}$ & 6 & 6.06 & & & & $x$ & & & & $x$ & $x$ & & & & & & & $x$ & $x$ & & & & $x$ & & & & \\
\hline $\begin{array}{l}\text { To improve } \\
\text { communication skills }\end{array}$ & 5 & 5.05 & & & & $x$ & & & & & & & & & $x$ & & $x$ & & & & $x$ & & & & $\mathrm{x}$ & & \\
\hline To be more sociable & 5 & 5.05 & $x$ & & $x$ & $x$ & $x$ & $x$ & & & & & & & & & & & & & & & & & & & \\
\hline Total & 99 & 100.00 & 6 & 5 & 9 & 4 & 4 & 4 & 4 & 4 & 4 & 4 & 3 & 3 & 4 & 3 & 4 & 4 & 4 & 2 & 5 & 3 & 4 & 3 & 3 & 3 & 3 \\
\hline
\end{tabular}

Source: authors. 


\section{Theft risk:}

CS24: “Theft risk maybe I can say yes, I think they sold me things more expensive in gift shop. I got robbed during my holiday and some transportation problems".

Phenomenological codes regarding participants' views on the effect of $\mathrm{CS}$ activities on cultural interaction, cultural tourism and socialising are given in Table 6. In this context, thirteen phenomenological codes have been described including discovering new cultures and cultural synthesis, making friends from different cultures, meeting people from different cultures, discovering new things, broadening horizons and knowledge, new experiences (gastronomy, travel, etc.), experiencing the destination culture in its natural environment, learning different languages, realizing dreams, contributing to cultural tourism, being helpful, sharing, anti-racist and hospitable, improving communication skills and being more sociable. Accordingly, more effective elements included "broadening horizons and knowledge (14.14\%; $\mathrm{n}=14)$, discovering new cultures and cultural synthesis $(13.13 \% ; n=13)$, making friends from different cultures $(12.12 \% ; n=12)$ and meeting people from other cultures $(10.10 \% ; n=10) "$. The views of some participants in this regard are as follows.

CS1: “While you are travelling you are learning different cultures, people, traditions so it's useful that you are having friends from different cultures, and you learn about their culture, and they learn about your culture so it's just good. It is extremely helpful for society, as it widens knowledge about other cultures".

CS2: "I saw a different country, I met new people, I tried new foods... so I can say it improved my cultural knowledge. İt is also a great contribution to local interaction which is the core concept of traveling. It's an opportunity to meet people from other countries with a different culture. CS allows you interact with foreigners and know about the culture".

CS3: "It's nice to know about different cultures, languages etc... and CS is useful to learn a new culture, cooking of that country and people. It can contribute, you can have friend from every nation".

CS21: "A lot because I can find out about other cultures like I mentioned before and that's awesome because I didn't know anything before and now I can understand a lot of things about them and that's great for me. It's something for people to connect and share experiences. So, it amazingly contributes and serves cultural tourism. It is a way to find out about other countries!".

CS5: "It has positive effects for socializing. I met new friends there we even share our numbers to each other so it's absolutely positive in the good way you are having so many new friends. CS is founded for socialising already. It's one hundred percent positive, they have positive effects by providing channels of communication, peace, tolerance, between people able and willing to socialize with those from other countries and even be hosted by/host them".

Table 7 (see p. 49) shows the phenomenological codings for participants' opinions about CS in travel culture. In this context, a total of eleven codes have been presented including simplification of accommodation expectations, low-budget vacation expectations, poor service from tour operators and hotels, preference for second homes, being more cautious, sharing economy tourism concept, increasing travel frequency with high travel motivation, 'bleisure' tourism, increasing participation in alternative tourism (widening the range) and holidays with ordinary people from other cultures. In this context, "giving up on tour operators and hotels" $(20.51 \% ; n=8)$, "simplification of accommodation expectations" (17.95\%; $n=7)$, "low-budget vacation expectations" (17.95\%; $n=7)$, "preference for idle and non-capacity second residences" (homeowners' houses) $(10.26 \% ; \mathrm{n}=4)$ and the "sharing economy tourism concept" $(10.26 \% ; n=4)$ were prominent.

In this sense, it can be said that CS, which is a new trend in tourism, contains transformations that may usher in a new era in the tourism sector. Thanks to CS, tourism activities on a lower budget, without the need for hotels and tour operators, through the sharing economy and by adding a new dimension to secondary residences. The use of the sharing economy and secondary residence can be evaluated as capacity saving and considered as an innovative activity. The views of participants in this respect are as follows.

CS6: “To simplify accommodation expectation. It's cheaper than other ways and its more enjoyable and people can help each other with like that. You know other ways of travelling can be expensive. it's better than tour agencies and hotels. Its free (mostly) and you can travel better than any tour organization".

CS3: "A lot we must take care of ourselves 10 times more and that's more difficult to travel. I know more about other cultures. I'm more motivated to travel around the world. Looking for remote jobs so I can travel at the same time because a lot of hosts I had were doing such jobs".

CS5: "It changed my travel culture - owing to CS I met many foreign people, and I improved my English skills. I discovered that young people are very welcoming. It widens my options for traveling".

Figure 1 presents a word cloud with expressions that CS participants gave in their answers to open-ended questions. While the word cloud algorithm positions centrally the most important words in the form of larger font sizes, it puts less important words into smaller ones (Voyant-tools, 2021). Figure 1 shows that participants position centrally the words "CS ", "new", "culture", "people", "traveling", "different", "countries", "know", "experience "and "risk" in the form of larger font sizes. 
Accordingly, the visual findings obtained from the word cloud, a qualitative analysis method, are consistent with the content analysis and coding analysis findings in the study. It can be said that CS activities underlie experiencing differences such as knowing new people, sightseeing new places, discovering new cultures, traveling and acquiring new knowledge.

The present results show that CS may be a popular tourism trend based on the sharing economy that incorporates people traveling to experience such differences.

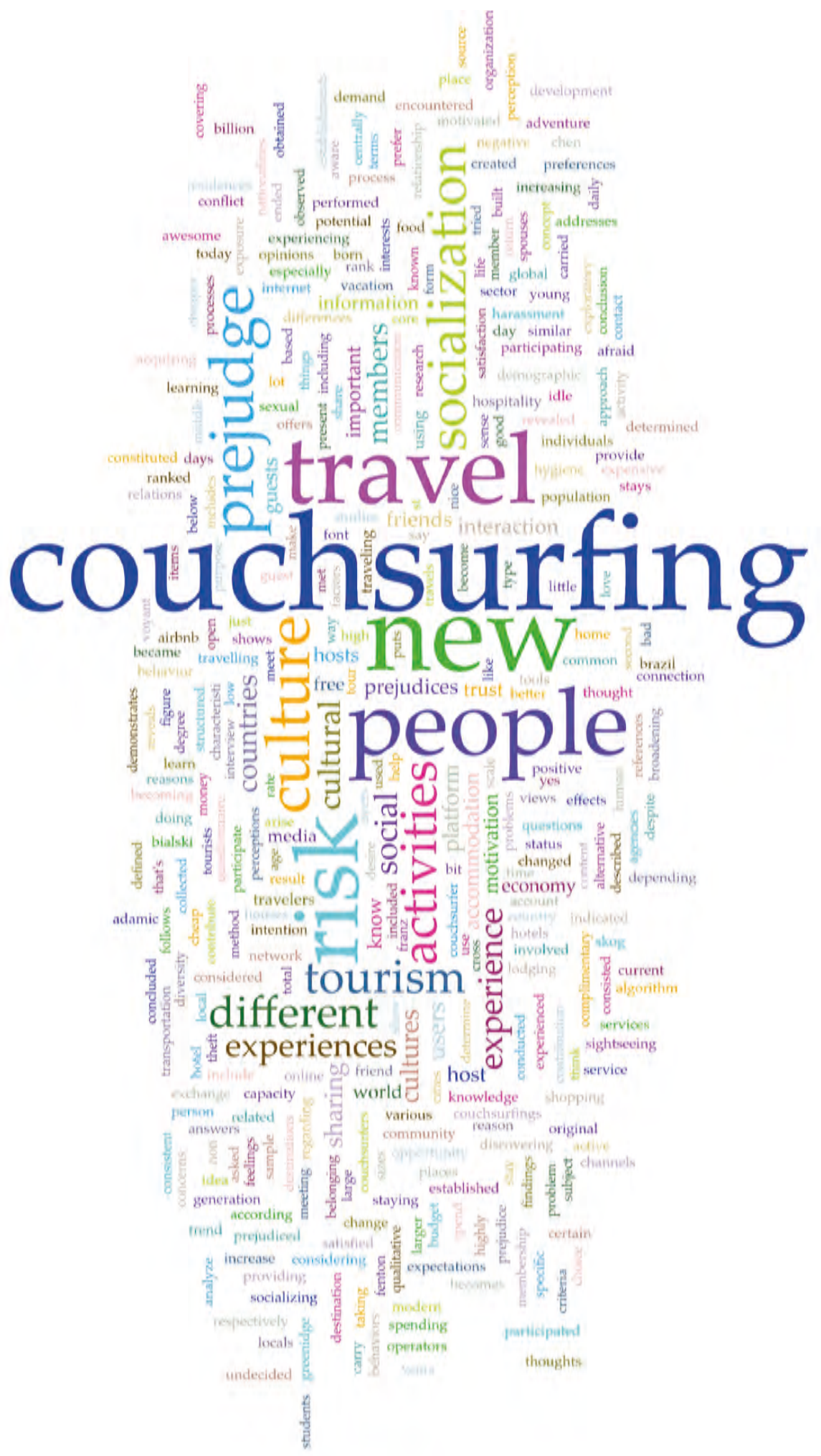

Figure 1. Word Cloud for expressions used by couchsurfing participants Source: authors 
Table 7. Phenomenological codings for participant views on the effects of CS

\begin{tabular}{|c|c|c|c|c|c|c|c|c|c|c|c|c|c|c|c|c|c|c|c|c|c|c|c|c|c|c|}
\hline$\frac{8}{8}$ & $\mathrm{z}$ & $\therefore$ & $\bar{y}$ & $\tilde{\mho}$ & $\tilde{U}^{3}$ & $\ddot{U}$ & 歺 & गे & ठิ & 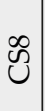 & के & $\begin{array}{l}0 \\
\overline{\tilde{\nu}} \\
\text { | }\end{array}$ & $\overline{\vec{n}}$ & $\frac{7}{3}$ & $\begin{array}{c}n \\
\vec{v}\end{array}$ & $\begin{array}{l}\vec{y} \\
\tilde{v}\end{array}$ & $\frac{10}{\overrightarrow{0}}$ & $\begin{array}{l}0 \\
\vec{U}\end{array}$ & $\widehat{\vec{\nu}}$ & $\frac{\infty}{\vec{v}}$ & $\overrightarrow{\vec{\nu}} \mid \xi$ & 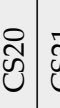 & \begin{tabular}{l|l}
$\vec{y}$ & $\delta$ \\
$\tilde{U}$ & 0
\end{tabular} & 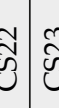 & Uే & సิ \\
\hline $\begin{array}{l}\text { Simplified } \\
\text { accommodation } \\
\text { expectations }\end{array}$ & 7 & 17.95 & $\mathrm{x}$ & $x$ & & & & $x$ & & & & $x$ & & & & & $\mathrm{x}$ & & & & & & $\mathrm{x}$ & & $\mathrm{x}$ & \\
\hline $\begin{array}{l}\text { Low budget holiday } \\
\text { expectations }\end{array}$ & 7 & 17.95 & $\mathrm{x}$ & & & & & $\mathrm{x}$ & $\mathrm{x}$ & & & & $\mathrm{x}$ & & & $\mathrm{x}$ & & & & $\mathrm{x}$ & $\mathrm{x}$ & & & & & \\
\hline $\begin{array}{l}\text { Not getting service } \\
\text { from tour operators } \\
\text { and hotels }\end{array}$ & 8 & 20.51 & & $\mathrm{x}$ & & $\mathrm{x}$ & & $x$ & & $\mathrm{x}$ & & & & $\mathrm{x}$ & & & & & $\mathrm{x}$ & & & $\mathrm{x}$ & & $\mathrm{x}$ & & \\
\hline Second home tourism & 4 & 10.26 & & $x$ & & & & & & & & & $\mathrm{x}$ & & & & & $\mathrm{x}$ & & & & & & $x$ & & \\
\hline Being more cautious & 1 & 2.56 & & & $\mathrm{x}$ & & & & & & & & & & & & & & & & & & & & & \\
\hline $\begin{array}{l}\text { Sharing economy } \\
\text { tourism concept }\end{array}$ & 4 & 10.26 & & $\mathrm{x}$ & & & & & & & $\mathrm{x}$ & & & & & & & & & & $\mathrm{x}$ & & & & & $\mathrm{x}$ \\
\hline $\begin{array}{l}\text { High travel } \\
\text { motivation, increased } \\
\text { travel frequency }\end{array}$ & 1 & 2.56 & & & $\mathrm{x}$ & & & & & & & & & & & & & & & & & & & & & \\
\hline $\begin{array}{l}\text { 'Bleisure' tourism, } \\
\text { remote working }\end{array}$ & 1 & 2.56 & & & $\mathrm{x}$ & & & & & & & & & & & & & & & & & & & & & \\
\hline $\begin{array}{l}\text { More alternative } \\
\text { tourism }\end{array}$ & 2 & 5.13 & & & & & $\mathrm{x}$ & & & & & & & & $\mathrm{x}$ & & & & & & & & & & & \\
\hline $\begin{array}{l}\text { Having holidays } \\
\text { with different people } \\
\text { from other cultures } \\
\text { and demographic }\end{array}$ & 2 & 5.13 & & & & & $\mathrm{x}$ & & & & & & & & & & & & & $\mathrm{x}$ & & & & & & \\
\hline Language tourism & 2 & 5.13 & & & & & $\mathrm{x}$ & & & & & & & & & & & & & & & & $x$ & & & \\
\hline Total & 39 & 100.00 & 2 & 4 & 3 & 1 & 3 & 3 & 1 & 1 & 1 & 1 & 2 & 1 & 1 & 1 & 1 & 1 & 1 & 2 & 2 & \begin{tabular}{l|l}
1 & 2 \\
\end{tabular} & \begin{tabular}{l|l}
2 & 1 \\
\end{tabular} & \begin{tabular}{l|l}
1 & 1
\end{tabular} & 1 & 1 \\
\hline
\end{tabular}

Source: authors.

\section{DISCUSSION AND CONCLUSION}

The present results reveal that the most important motivation factor for couchsurfers is innovation. In this context, it was found that the desire to sightsee new places, meet new people and recognize different cultures has motivated the participants. This result agrees with the findings of Ayers-Greenidge (2012).

Although this study shows that most participants did not have any reservations or risk perceptions, those taking part in CS for the first time were initially prejudiced against it. This is parallel with the findings of Dén-Nagy and Király (2014). However, it has been concluded that some prejudiced participants have encountered various problems (hygiene, sexual harassment, and theft) during the CS experience. Nevertheless, it has been found that a good part of the participants with a prejudice before their first CS experience overcame it subsequently. Skog (2012) concluded that the prejudices of some participants have changed over time.

The couchsurfers participating in the study have experienced many CS trips, are generally highly satisfied with their hosts and have the intention of traveling as CS again. This result is consistent with the findings of Franz (2012). In addition, the presence of many participants who have experienced CS trips more than 10 times shows it has transformed itself into a travel culture, as in the study of Chen (2018). Moreover, it has been found that CS contributes significantly to the cultural interaction and socialising among the participants. This result is also in line with Skog (2012).

The results are similar to Ayers-Greenidge (2012) but not to those of Şahbaz (2019). This may arise from the fact Şahbaz's sample was taken from a single country and the motivation factors evaluated were completely different. In addition, the results reported by Moreira and Gomes (2018) differ from the present results. It seems that the factors indicated by the participants as encouraging them to choose couchsurfing show no similarity to the motivations mentioned in this work, which probably results from the distinctness of the sample (only Brazil). Pultar, Raubal, Goulias (2012) conducted a large-scale study involving 228 members registered on the CS platform from 40 different countries. However, they aimed only to determine the demographic characteristics of the participants and whether they used the platform as a guest or host. In this regard, although their study shows similarities with the present one in terms of covering a large number of different countries, it is different in 
terms of purpose. Therefore, similar results could not be achieved.

Other different results were found from other studies (Chen, 2018; Moreira, Gomes, 2018; Pultar, Raubal, Goulias, 2012; Şahbaz, 2019). For example, the present study finds that the participants generally do not prefer to participate in CS activities alone. It has been thought that this has arisen from the desire to reduce the risks that may occur at the accommodation. It can also be said that the participants have a desire to engage in activities with individuals who have common motivations and purposes.

Participants of CS activities have a low-budget vacation following the logic of sharing economy without including basic tourism establishments such as travel agencies and accommodation establishments. However, CS participants do spend on food and beverages, transportation, souvenirs, etc., apart from finding free accommodation through this platform in the countries or destinations travelled to. This may result in an increase in numbers participating in tourism activities, but a decrease in tourism expenditure.

In conclusion, widespread CS activities, a rising trend, may be a transformative for the tourism sector. In this sense, it may seem inevitable that all stakeholders follow this transformation process closely and keep up with it. Otherwise, tourism destinations and establishments that cannot show flexibility or adapt to these innovations may not stay in business. Today, the sense of customer-driven modern marketing has caused the demand to have a voice in the conflict between supply and demand. Phenomenological quotations from participants also support these results. Due to these reasons, investigation into initiatives such as CS, which is an example of the sharing economy and an alternative solution-driven approach to consumers, would contribute to the body of literature. For this reason, further studies should focus on other current issues such as Airbnb, Eatwith and Trip4Real.

\title{
BADANIA FENOMENOLOGICZNE DOŚWIADCZEŃ OSÓB KORZYSTAJĄCYCH Z COUCHSURFINGU
}

\author{
Halil İbrahim Karakana (D), Kemal Birdirb (D), Aliye Akinc (D), Adnan Akin
}

\footnotetext{
a Badacz niezależny; http://orcid.org/0000-0003-3335-0923; e-mail: hikarakan@gmail.com

b Uniwersytet Mersin, Katedra Turystyki; https://orcid.org/0000-0003-1353-3618; e-mail: kemalbirdir@mersin.edu.tr

c Uniwersytet Abant Izzet Baysal w Bolu, Katedra Turystyki; https://orcid.org/0000-0001-8589-7547; e-mail: aliye.akin@ibu.edu.tr

${ }^{d}$ Uniwersytet Abant Izzet Baysal w Bolu, Szkoła Zawodowa w Bolu; https://orcid.org/0000-0002-7023-1678;

e-mail: adnan.akin@ibu.edu.tr
}

Sposób cytowania (styl APA): Karakan, H.I.., Birdir, K., Akin, A., Akin, A. (2021). Phenomenological research on guest couchsurfing experience. Turyzm/ Tourism, 31 (2), 39-63. https://doi.org/10.18778/0867-5856.31.2.03

\begin{abstract}
ABSTRAKT
Couchsurfing (CS) jest obecnie uważany za alternatywną platformę, która odzwierciedla zmiany w preferencjach dotyczących zakwaterowania turystycznego. Serwis CS, oparty na ekonomii współdzielenia, daje możliwość zaoferowania podróżnym różnorodnych doświadczeń turystycznych oraz zakwaterowania. Celem niniejszego artykułu jest przedstawienie informacji na temat związanych z podróżowaniem motywacji, uprzedzeń, doświadczeń osób korzystających z couchsurfingu oraz postrzegania przez nie ryzyka. Artykuł stanowi oryginalną wartość w literaturze przedmiotu, jako że jest w nim zgłębiane zagadnienie użytkowników wspomnianego portalu w aspekcie fenomenologicznym. Wyniki najnowszych badań świadczą o tym, że pragnienie zwiedzania miejsc, w których się wcześniej nie było, poznawania nowych ludzi i różnych kultur motywuje uczestników. Analizy pokazują że większość uczestników couchsurfingu nie miała uprzedzeń ani wrażenia istnienia ryzyka, jednak osobom, które wybrały tę formę zakwaterowania po raz pierwszy, towarzyszyły takie odczucia. Zaobserwowano również, że uczestnicy są bardzo zadowoleni ze swoich doświadczeń związanych $\mathrm{z}$ couchsurfingiem i zamierzają ponownie skorzystać $\mathrm{z}$ tego rozwiązania.
\end{abstract}

\section{SŁOWA KLUCZOWE}

couchsurfing, turystyka, zakwaterowanie, podróże, ekonomia współdzielenia

\section{INFORMACJE O ARTYKULE}

Przyjęto:

3 kwietnia $2021 \mathrm{r}$.

Zaakceptowano:

15 września 2021 r

Opublikowano:

3 grudnia $2021 \mathrm{r}$. 


\section{WSTĘP}

W miarę rozwoju i popularyzacji technologii informacyjnej coraz więcej osób na całym świecie korzysta z Internetu. Nowe technologie mogą być pomocne w wyszukiwaniu istotnych informacji, ludzi i grup, umożliwiając w ten sposób komunikację (İmre, 2020). Sieć komunikacyjna o wielkiej przepustowości, znacznie przekraczającej możliwości ludzkiego mózgu, została rozbudowana na skalę globalną. Wraz z postępem technologii cyfrowej gwałtownie rozwijają się media społecznościowe - platformy internetowe, na których osoby o podobnych zainteresowaniach dzielą się swoimi wrażeniami i myślami (Weber, 2009). Raport Digital 2020: Global digital overview pokazuje, że 59\% ludzi na świecie (ok. 4,54 mld) korzystało dotychczas z Internetu. Co więcej, 92\% z nich (4,18 mld) to również użytkownicy Internetu mobilnego. Według tego samego raportu $49 \%$ populacji (ok. 3,80 mld osób) stanowią aktywni użytkownicy mediów społecznościowych (We are social, 2021).

Media społecznościowe to strony Web 2.0, które skupiają ludzi na platformie wirtualnej, zapewniają głębokie interakcje poprzez przynależność do silnej społeczności oraz umożliwiają implementację wspólnych projektów (Brown, 2009). Dlatego też media społecznościowe, które dają użytkownikowi możliwość członkostwa i tworzenia treści, zapewniając jednocześnie interakcje społeczne i oferując usługi online, stały się integralną częścią naszego codziennego życia (Başarangil, 2019). Dzięki temu odgrywają znaczącą rolę w różnych sektorach, zwłaszcza w branży usługowej (Aktan, 2018). Pełnią one również ważną funkcję w sektorze turystycznym, wymagającym dużych nakładów pracy, i nadają szczególne znaczenie relacjom międzyludzkim w kontekście dzielenia się doświadczeniami turystycznymi, jednocześnie umożliwiając rozwój wszystkim zaangażowanym interesariuszom (Huang, Goo, Nam, Yoo, 2017). Turyści powszechnie korzystają z różnych narzędzi dostępnych w mediach społecznościowych, aby zdecydować, gdzie chcieliby wyjechać na wakacje (Xiang, Gretzel, 2010). Stało się to nawet kluczowe dla zapewnienia sobie satysfakcji turystycznej i rozwoju (Anderson, 2012). Rozwój platform społecznościowych oraz wzrost liczby osób, które z nich korzystaja, powoduje zmiany w relacjach i komunikacji między samymi turystami oraz między turystami i osobami obsługującymi ruch turystyczny.

Dzięki platformom społecznościowym turyści mogą szybko i wygodnie dzielić się swoimi doświadczeniami z podróży. Posty umieszczane w takich portalach stały się ważnym źródłem informacji, które mogą wpłynąć na decyzje podróżnicze potencjalnych gości. Jednym z takich serwisów jest Couchsurfing (CS) (Kang, Schuett, 2013), który można określić jako platformę stanowiącą odzwierciedlenie nowego trendu w zapotrzebowaniu na zakwaterowanie w sektorze turystycznym. Na platformie Couchsurfing dostępne są oferty zlokalizowanych na całym świecie, bezpłatnych noclegów dla osób podróżujących.

\section{COUCHSURFING}

Couchsurfing (CS) - platforma non profit oparta na ekonomii współdzielenia, w której pieniądze nie są używane jako środek wymiany usług - jest światową siecią stworzoną po to, by łączyć podróżujących i odwiedzane przez nich lokalne społeczności (Lauterbach, Truong, Shah, Adamic, 2009). Couchsurfing służy podróżującym, zwłaszcza w kwestii wyboru zakwaterowania. Jest to organizacja, która pełni wiele funkcji, takich jak: skupianie użytkowników z różnych destynacji w jednym miejscu, umożliwianie im nawiązywania kontaktów i przekazywania informacji na temat poszczególnych miejscowości (Chung, Buhalis, 2009).

Na pomysł couchsurfingu wpadł Casey Fenton podczas podróży do Islandii w 1999 r. Fenton, chcąc znaleźć tanie lokum, wysyłał e-maile z pytaniem o możliwość zakwaterowania do osób studiujących w Reykjaviku (Molz, 2012). W odpowiedzi otrzymał ponad 50 zaproszeń. Po powrocie do USA chciał się podzielić swoimi doświadczeniami. W 2004 r. stworzył w tym celu stronę internetową i tak właśnie powstał Couchsurfing - sieć, za pomocą której podróżnicy z całego świata kontaktują się z osobami oferującymi zakwaterowanie (gospodarzami) (Rosen, Lafontaine, Hendrickson, 2011).

Członkostwo w sieci CS wymaga weryfikacji i rekomendacji. Osoby należące do CS potwierdzają swoją tożsamość i adres za symboliczną opłata, co jest ważne, ponieważ umożliwia zdobycie zaufania innych użytkowników. Rekomendacje to oceny i komentarze pozostawiane przez członków na profilach innych osób. Członek, który zdobył doświadczenie i zyskał miano couchsurfera, powinien zamieścić swoją ocenę po pobycie - pozytywna, neutralną (niezdecydowany) lub negatywną (Lauterbach, Truong, Shah, Adamic, 2009). Po przejściu przez tę procedurę członkowie mogą poszukiwać gospodarzy w konkretnych miejscowościach, wysyłać zapytania o zakwaterowanie, dołączać do grup dyskusyjnych złożonych z aktywnych użytkowników, dzielących się uwagami za pośrednictwem omawianej platformy. Typowym procesem CS jest utworzenie listy potencjalnych gospodarzy w danej miejscowości i kontaktowanie się z nimi w celu zapytania o możliwość pobytu. W ten sposób zarówno gospodarze, jak i goście przeglądają wzajemnie swoje profile w poszukiwaniu informacji. W miarę ukonkretniania się planów, coraz bardziej prawdopodobne staje się, że gospodarze i goście wymienią się informacjami, takimi jak adres e-mail i numer telefonu, oraz zaakceptują ofertę zakwaterowania (Molz, 2012). Gospodarze nie tylko udostępniają 
gościom własny dom, ale również poświęcają im swój wolny czas i dzielą się innymi zasobami (Bialski, 2012).

„Dziel się swoim życiem i kultura, nawiąż kontakt, okazuj życzliwość, bądź ciekawy i pozostaw po sobie nocleg w lepszym stanie, niż go zastałeś" - to główne zasady couchsurfingu. Dzięki temu platforma może zaoferować użytkownikom pełną znaczeń i alternatywną trasę zwiedzania, obfitującą w emocje, wrażenia, doświadczenia i cechy indywidualne, stanowiącą dodatek do darmowego zakwaterowania. Z korzystaniem z platformy wiążą się również takie wartości, jak: interakcje międzyludzkie, poznawanie samego siebie i odpowiedzialność społeczna (Zgolli, Zaiem, 2018 ).

Obecnie platforma CS jest społecznością globalną, składającą się z 14 mln użytkowników, dzielących się swoim życiem, światem i podróżami do ponad 200 tys. destynacji w niemal 180 krajach (Couchsurfing, 2021). Przeciętny wiek couchsurfera to 28 lat. CS jest najbardziej popularny wśród młodych ludzi w wieku 18-34 lata, którzy stanowią 37,9\% ogólnej liczby użytkowników. Osoby powyżej 50. roku życia stanowią ok. 2\% członków społeczności CS (Hanchuk, Bondarenko, Varfolomyeyeva, Pakhomova, Lohvynenko, 2020).

Można zatem stwierdzić, że przynależność do tej sieci społecznościowej jest typowa raczej dla podróżników młodych i w średnim wieku, urodzonych w latach 80. i 90. XX w., należących do tzw. pokolenia Y. Powszechnie wiadomo, że ludzie urodzeni pod koniec lat 90 . bardziej polegają na technologii, Internecie i mediach społecznościowych niż osoby starsze, ponadto prowadzą oni odmienny styl życia i wyznają inne idee. W istocie, można uznać, że pojawiła się generacja, która potrzebuje ciągłej interakcji za pośrednictwem tych kanałów komunikacji (Doyle, 2016). Użytkowników z pokolenia $Y$, którzy zdobywają doświadczenia wakacyjne z wykorzystaniem platformy CS, zazwyczaj nie zadowala zwykła aktywność turystyczna. Wolą zdobywać nowe i inne doświadczenia, dzieląc wspólne wartości. Dlatego można stwierdzić, że platforma CS zwiększa mobilność związaną z podróżami oraz nadaje inny koloryt turystyce i przemysłowi turystycznemu.

\section{PRZEgląd Literatury}

Dzięki platformie CS podróżujący z całego świata mogą się spotykać i nawiązywać kontakty międzykulturowe i społeczne. $Z$ tego powodu CS stał się przedmiotem zainteresowania naukowców reprezentujących różne dyscypliny, czego skutkiem jest pojawieniem się wielu krajowych i międzynarodowych badań dotyczących tego serwisu. Wygląda na to, że badania te ukierunkowane są głównie na użytkowników platformy CS, tj. gospodarzy i gości. W tym kontekście niektóre studia koncentrują się na społeczno-kulturowo-ekonomicznych oraz demograficznych cechach członków platformy, powodach, dla których stali się częścią tej społeczności, sposobach korzystania z portalu oraz tworzenia profili i ich zawartości, a także na efektach. Badacze zajmują się również działaniem mechanizmu wzajemnego zaufania, oraz rolą systemu rekomendacji w udostępnianiu kultury.

Chen (2018) badał zachowania uczestników CS zarówno w Internecie, jak i poza nim, w tym pewne podejmowane przez nich ukryte, niewłaściwe działania, mając na celu poznanie powodów, dla których omawiany serwis przekształcił się z prostej sieci wymiany zakwaterowania w specyficzny styl podróżowania. Badania te ujawniły, że użytkownicy zaczęli preferować wakacje w ramach wymiany gości, jako że platforma daje uczestnikom możliwość interakcji kulturowej i tworzy przyjazne i tolerancyjne środowisko wakacyjne. Spitz (2017) zbadała poziomy interakcji międzykulturowej Turków w odniesieniu do doświadczeń CS, opierając się na różnych teoriach kulturowych. Badanie wykazało, że platforma umożliwia międzykulturowe porównania i stwarza kosmopolityczne pragnienie wymiany kulturowej pod względem otwartości i odmienności. Spitz (2017) wskazała, że kapitał społeczny i kulturowy stał się elementem, który można wymieniać za gościnność poprzez sieć społecznościową. W swojej pracy pt. Kosmopolitanizmy Couchsurfingu: Czy turystyka może uczynić świat lepszym? Picard i Buchberger (2013) skupiają się na porównaniu turystyki modernistycznej z postmodernistyczną. Wskazują oni, iż CS pomaga zarówno mieszkańcom danej lokalizacji, jak i turystom uciec od wycieczek zorganizowanych, popularnych we współczesnej turystyce, oraz że zmiany społeczno-kulturowe mogą otworzyć drzwi do świata, w którym żyje się przyjemniej. Badacze stwierdzili również, że bezpośrednie i głębokie relacje między gospodarzami a gośćmi zostały nawiązane za pośrednictwem platform hotelarskich bez udziału jakichkolwiek mechanizmów kontrolnych, zmieniając $\mathrm{w}$ ten sposób hotelarstwo związane z turystyką.

Moreira i Gomes (2018) przeprowadzili badania dotyczące gospodarzy i gości zarejestrowanych na platformie CS w gminie Jaguarão - najbardziej wysuniętej na południe części Rio Grande do Sul w Brazylii. Studia te miały na celu identyfikację i omówienie zainteresowań i motywacji ich uczestników, których poproszono o wypełnienie częściowo ustrukturyzowanego kwestionariusza online oraz offline. Wynika z niego, że czynniki, które przyczyniają się do tego, że gospodarze i goście korzystają z CS, to: zakupy w strefie bezcłowej, odwiedziny u krewnych, rozwijanie zainteresowań zawodowych oraz cieszenie się czasem wolnym podczas wakacji. Schuckert, Peters i Pilz (2017) przeprowadzili wywiad z 14 osobami w Austrii, z wykorzystaniem częściowo ustrukturyzowanego kwestionariusza, aby określić motywacje członków CS do podróżowania i udzielania gościny. Badacze stwierdzili, że uczestnicy 
CS - ogólnie rzecz biorąc - wchodzą w różne interakcje społeczne z mieszkańcami obszaru, który odwiedzaja, aby uzyskać informacje na jego temat. Ponadto stwierdzili, że relacja gospodarz-gość nabiera charakteru wymiany międzykulturowej oraz autentyczności. Ayers-Greenidge (2012) podjęła próbę określenia motywacji i cech osobowości tajwańskich członków CS. Badania wykazały, że uczestnicy charakteryzowali się otwartością na doświadczenia, ekstrawertyzmem i konfliktowością. Ponadto autor stwierdził, że członków motywowały także możliwość interakcji kulturowej i samorealizacji, poszukiwanie różnych doświadczeń, ciekawość i zainteresowanie odmiennymi stylami życia.

Dén-Nagy i Király (2014) przeprowadzili badania, których celem było zademonstrowanie, jak działa Couchsurfing pomimo potencjalnego ryzyka i niepewności oraz jak zmienił się w rozwijającą się i odnoszącą sukcesy platformę. Wspomniani autorzy w latach 2012-2013 byli zaangażowani $\mathrm{w}$ realizację jakościowego projektu badawczego na Węgrzech, na podstawie którego stwierdzili, że wysoki poziom zaufania wśród użytkowników zwiększa motywację i prowadzi do silnych interakcji kulturowych. Badacze wykazali również, że członkowie CS postrzegają ryzyko jako niskie oraz że budują zaufanie, opierając się na emocjach. Franz (2013), koncentrując się na platformie CS i wymianie zakwaterowania, w swojej pracy magisterskiej, zatytułowanej CouchSurfing: Experiences, reputation, references and decision-making in an online hospitality network, przeanalizowała modele zachowań kształtujące się po negatywnym doświadczeniu, które podróżni mieli podczas pobytu. Przeprowadziła wywiady online z 35 osobami i stwierdziła, że niepokoiły się one o swój status i reputację wynikającą z negatywnych doświadczeń i rekomendacji. Odkryła również, że z powodu tych obaw użytkownicy unikali nawet zamieszczania pozytywnych opinii.

Pultar, Raubal i Goulias (2012) określili zwyczaje członków platformy CS na podstawie ich cech demograficznych i danych geograficznych. W tym celu poprosili 228 uczestników z 40 różnych krajów o wypełnienie kwestionariusza. Badacze stwierdzili, że starsi użytkownicy platformy szukają zakwaterowania częściej niż młodsi, a mężczyźni są bardziej niż kobiety zaangażowani $\mathrm{w}$ couchsurfing jako goście. Ponadto zaobserwowali, że pojedynczy użytkownicy Couchsurfing.com na obszarach słabo rozwiniętych gospodarczo, takich jak Ameryka Łacińska i Azja, korzystają z tej platformy głównie jako właściciele domu.

\section{METODYKA BADAŃ}

Celem badań było określenie motywacji wyjazdów, zachowań osób podróżujących, postrzegania ryzy$\mathrm{ka}$, uprzedzeń, poziomu satysfakcji oraz zamiaru powtórnego skorzystania z formuły couchsurfingu. Dodatkowo autorzy niniejszej publikacji chcieli zaprezentować sugestie dla potencjalnych użytkowników platformy na podstawie doświadczeń osób, które już z niej korzystały.

Jako że dotychczas nikt nie prowadził studiów nad wyjątkowym zjawiskiem couchsurfingu w odniesieniu do gości przy zastosowaniu podejścia fenomenologicznego, autorzy wykorzystali model badań eksploracyjnych. Są one opisywane jako typ badań przeprowadzanych $w$ celu zebrania wstępnych informacji pomagających zidentyfikować problemy, na temat których nie ma jeszcze szczegółowych informacji i należy je dopiero znaleźć. Następnie mogą być one wykorzystane do postawienia hipotezy. Stwierdzono, że użycie metod jakościowych byłoby właściwe w takich badaniach (Okumus, 2015), a dane mogą być zbierane z wykorzystaniem metody wywiadu.

Zgodnie z głównymi celami badań poszukiwano odpowiedzi na następujące pytania:

1. Jakie są motywacje podróżnicze uczestników couchsurfingu?

2. Jak osoby podróżujące jako couchsurferzy postrzegają ryzyko oraz jakie mają uprzedzenia?

Chociaż powstało wiele prac na temat gospodarzy w systemie CS, literatura odnosząca się do gości jest nader skromna. Autorzy nie natrafili na żadne studia fenomenologiczne dotyczące gości w działaniach CS. Badania opisane w niniejszym artykule mają oryginalną wartość, ponieważ zastosowano w nich podejście fenomenologiczne oraz jakościowe metody badawcze. Fenomenologia próbuje odkrywać najważniejsze znaczenia. W tego typu badaniach brane są pod uwagę opinie osób, które mają doświadczenie w danej kwestii, jak i same doświadczenia. Fenomenologia jest nauka, skoncentrowaną prawidłowo i bezstronnie na doświadczeniach, myślach i odczuciach, będących głównym źródłem informacji, jakie mają jednostki (Güler, Halıcıoğlu, Taşğin, 2013). Prowadzenie badań fenomenologicznych jest trudne, ale w ten sposób można uzyskać cenne informacje (Cope, 2003). Co więcej, w wyniku przeglądu literatury krajowej i międzynarodowej nie znaleziono publikacji odnoszącej się do różnych krajów, w których rozwija się couchsurfing. Niniejsze badania są zatem oryginalne i istotne, ponieważ zostały przeprowadzone na próbie gości CS będących reprezentantami 25 różnych narodowości.

Próba badawcza składała się z osób biorących udział w couchsurfingu. Podczas poszukiwania podróżnych korzystających z tego rozwiązania autorzy artykułu dotarli do trzech osób przez oficjalną platformę couchsurfingową oraz grupy CS w mediach społecznościowych (Facebook i Instagram) i przeprowadzili z nimi wywiady online. Następnie, wykorzystując metodę kuli śnieżnej, znaleźli innych uczestników i również przeprowadzili z nimi wywiady. Przy doborze przyjęto 
dwa kryteria - uczestnik musiał doświadczyć couchsurfingu jako gość oraz reprezentować narodowość inną niż pozostali.

Dane pozyskiwano, wykorzystując metodę wywiadu ustrukturyzowanego, zaczerpniętą z podejścia jakościowego. Informacje zbierano między 10 grudnia 2020 r. a 5 lutego 2021 r. Formularz kwestionariusza składał się z sześciu pytań otwartych na temat doświadczeń CS oraz sześciu pytań demograficznych (metryczka).

Dane zebrane od uczestników w wywiadach zostały opisane metodą fenomenologiczną. Co więcej, odpowiedzi na niektóre pytania zostały opracowane cyfrowo i przedstawione $\mathrm{w}$ tabelach, natomiast inne zostały podzielone tematycznie, za pomocą analizy treści. Autorzy, wykorzystując aplikację Voyant Tools, utworzyli chmury wyrazowe lub chmury tagów. Chmura wyrazowa to wizualna reprezentacja słów występujących w podawanych przez uczestników odpowiedziach na pytania otwarte. Wyrazy te - w zależności od częstotliwości występowania - są odpowiednio eksponowane i umieszczane w bardziej lub mniej centralnej pozycji. Algorytm analizy chmury wyrazowej plasuje centralnie najważniejsze słowa zapisane większym stopniem pisma, a mniej istotne - mniejszym (Voyant-tools, 2021).

\section{WYNIKI}

W pierwszej kolejności zostaną zaprezentowane dane dotyczące cech demograficznych respondentów. Następnie autorzy przedstawią opinie na temat motywacji uczestników mających doświadczenie z couchsurfingiem oraz postrzegania przez nich ryzyka, ich uprzedzeń, problemów, jakie napotkali, poziomu satysfakcji, zamiaru ponownego uczestnictwa, poziomu socjalizacji, jak również zachowań w podróży oraz interakcji kulturowych.

W tabeli 1 zaprezentowano cechy demograficzne uczestników. Badanie objęło 25 różnych użytkowników

Tabela 1. Dane demograficzne dotyczące uczestników

\begin{tabular}{|c|c|c|c|c|c|c|}
\hline Uczestnicy & $\begin{array}{c}\text { Kraj } \\
\text { pochodzenia }\end{array}$ & Zawód & Wiek & Stan cywilny & Płeć & Wykształcenie \\
\hline Couchsurfer 1 & Turcja & wojskowy & 27 & kawaler & mężczyzna & absolwent uniwersytetu \\
\hline Couchsurfer 2 & Chiny & fotograf & 38 & zamężna & kobieta & absolwentka uniwersytetu \\
\hline Couchsurfer 3 & Francja & student & 25 & panna & kobieta & absolwentka uniwersytetu \\
\hline Couchsurfer 4 & Japonia & pielęgniarka & 32 & panna & kobieta & absolwentka uniwersytetu \\
\hline Couchsurfer 5 & Maroko & handlowiec & 35 & panna & kobieta & tytuł magistra lub wyżej \\
\hline Couchsurfer 6 & USA & kierowca taksówki & 29 & kawaler & mężczyzna & szkoła średnia lub niżej \\
\hline Couchsurfer 7 & Filipiny & pokojówka & 34 & panna & kobieta & szkoła średnia lub niżej \\
\hline Couchsurfer 8 & Brazylia & kelnerka & 36 & panna & kobieta & szkoła średnia lub niżej \\
\hline Couchsurfer 9 & Meksyk & fryzjer & 38 & panna & kobieta & absolwentka uniwersytetu \\
\hline Couchsurfer 10 & Pakistan & lekarz & 24 & kawaler & mężczyzna & absolwent uniwersytetu \\
\hline Couchsurfer 11 & Włochy & sekretarka & 41 & kawaler & mężczyzna & absolwent uniwersytetu \\
\hline Couchsurfer 12 & Grecja & oficer bezpieczeństwa & 31 & żonaty & mężczyzna & absolwent uniwersytetu \\
\hline Couchsurfer 13 & Chiny & doktorant turyzmu & 42 & kawaler & mężczyzna & tytuł magistra lub wyżej \\
\hline Couchsurfer 14 & Egipt & student & 22 & kawaler & mężczyzna & absolwent uniwersytetu \\
\hline Couchsurfer 15 & Cypr (Grecja) & wykładowca & 44 & kawaler & mężczyzna & tytuł magistra lub wyżej \\
\hline Couchsurfer 16 & Azerbejdżan & deweloper & 28 & kawaler & mężczyzna & szkoła średnia lub niżej \\
\hline Couchsurfer 17 & Kanada & kierownik budowy & 39 & kawaler & mężczyzna & absolwent uniwersytetu \\
\hline Couchsurfer 18 & Hiszpania & architekt & 35 & zamężna & kobieta & absolwentka uniwersytetu \\
\hline Couchsurfer 19 & $\begin{array}{c}\text { Wielka } \\
\text { Brytania }\end{array}$ & $\begin{array}{l}\text { programista } \\
\text { komputerowy }\end{array}$ & 28 & panna & kobieta & absolwentka uniwersytetu \\
\hline Couchsurfer 20 & Norwegia & muzyk & 27 & żonaty & mężczyzna & absolwent uniwersytetu \\
\hline Couchsurfer 21 & Niemcy & socjolog & 42 & zamężna & kobieta & absolwentka uniwersytetu \\
\hline Couchsurfer 22 & Izrael & tłumacz & 24 & żonaty & mężczyzna & absolwent uniwersytetu \\
\hline Couchsurfer 23 & Rosja & nauczyciel & 33 & panna & kobieta & absolwentka uniwersytetu \\
\hline Couchsurfer 24 & Australia & przewodnik wycieczek & 42 & panna & kobieta & tytuł magistra lub wyżej \\
\hline Couchsurfer 25 & Iran & student & 23 & zamężna & kobieta & absolwentka uniwersytetu \\
\hline
\end{tabular}

Źródło: opracowanie własne. 
platformy CS pochodzących z sześciu kontynentów i 25 krajów. Wśród respondentów było 12 mężczyzn i 13 kobiet, siedmioro $\mathrm{z}$ nich pozostawało $\mathrm{w}$ związku małżeńskim, a 18 było stanu wolnego. Były to osoby reprezentujące różne zawody oraz studenci. Badani mieścili się w przedziale wiekowym 22-44 lata, co oznacza, że byli to ludzie młodzi i w średnim wieku. Wśród ankietowanych było 21 osób, które mają przynajmniej tytuł licencjata.

W tabeli 2 zaprezentowano zachowania uczestników w kontekście codziennych wydatków, kupowanych artykułów (produkt/usługa), współuczestników, liczby odbytych podróży CS i średniej długości pobytu. Dane te sugeruja, że $24 \%$ uczestników praktycznie nie wydaje pieniędzy podczas wakacji CS ( $\mathrm{n}=6$; ranga 3$)$; $36 \%$ wydaje do 25 dolarów dziennie $(n=9$; ranga 1$)$; $28 \%-26-50$ dolarów ( $\mathrm{n}=7$; ranga 2 ). Biorąc pod uwagę wydatki, uczestnicy nie ponosili żadnych kosztów zakwaterowania, zgodnie z zasadami couchsurfingu. Największą część zakupów stanowiło jedzenie (44\%; $\mathrm{n}=15$ ). W odpowiedziach na pytanie dotyczące współtowarzyszy podróży na pierwszym miejscu uplasowali się inni użytkownicy platformy CS $(25,93 \%$; $=7)$. Inne osoby towarzyszące uczestnikom to: ich partnerzy $(22,22 \% ; n=6)$, bliscy przyjaciele $(14,81 \% ; n=4)$ oraz wirtualni znajomi $(11,11 \% ; n=3)$. Udział podróżujących w pojedynkę wynosił $18,62 \%(n=5)$. Pod względem częstości doświadczenia $80 \%$ uczestników wielokrotnie korzystało z formuły CS, dla pozostałych $20 \%$ był to pierwszy raz. Jeśli chodzi o długość pobytu, $20 \%$ uczestników $(n=5)$ spędziło $w$ wybranym miejscu tylko jedną noc, $14 \%(n=7)-4-5$ nocy, a $8 \%(n=4)-2-3$ noce. Liczba uczestników spędzających ponad tydzień wynosiła zaledwie $6 \%(n=3)$. Zaobserwowano, że chociaż couchsurferzy ponosili różne wydatki turystyczne, np. na wyżywienie, pamiątki czy zakupy, byli też tacy, którzy nie wydawali pieniędzy na zakwaterowanie, ale ogólnie podejmowali różne działania z innymi członkami platformy CS, partnerami lub osobami podróżującymi samotnie, przebywali $w$ danym miejscu przez jedną dobę lub do tygodnia oraz powtarzali doświadczenie couchsurfingu.

W tabeli 3 zawarto informacje dotyczące opinii uczestników na temat doświadczeń związanych z couchsurfingiem, takich jak: zadowolenie z gościnności gospodarza, wakacje CS, wkład CS w rozwijanie kontaktów społecznych oraz zamiar ponownego uczestnictwa.

Niemal wszyscy ankietowani $(96 \%, n=24)$ byli zadowoleni z gościnności gospodarzy, a $88 \%(n=22)$ wykazywało wysoki poziom satysfakcji. Jeden uczestnik był niezdecydowany. $Z$ kolei $92 \%(n=23)$ respondentów było zadowolonych $\mathrm{z}$ wakacji CS, jeden ankietowany był niezdecydowany i jeden niezadowolony. Spośród osób objętych badaniem 92\% ( $n=23)$ uznało, że wakacje CS miały duży wpływ na rozwijanie kontaktów towarzyskich, podczas gdy dwóch uczestników stwierdziło, że nie miało to znaczenia. Większość respondentów $(96 \%, \mathrm{n}=24)$ miała zamiar powtórzyć doświadczenie CS, w tym $88 \%(\mathrm{n}=22)$ było tego absolutnie pewnych. Jedna osoba (4\%) była niezdecydowana. Podsumowując, podróżni biorący udział w badaniu byli wysoce usatysfakcjonowani gościnnością i wakacjami CS oraz uznali, że zamierzają powtórzyć to doświadczenie. Co więcej, respondenci stwierdzili, że wakacje CS wzbogaciły ich życie towarzyskie.

Kody fenomenologiczne motywacji podróżowania typu CS zostały podane $\mathrm{w}$ tabeli 4 . Są one krótko określone jako: udział w czynnościach duchowych

Tabela 2. Zachowania podróżnicze uczestników

\begin{tabular}{|c|c|c|c|c|c|c|c|c|}
\hline \multirow{3}{*}{$\begin{array}{l}\text { Dzienne } \\
\text { wydatki }\end{array}$} & \multicolumn{2}{|c|}{ Brak } & \multirow{2}{*}{$\begin{array}{c}1-25 \text { USD } \\
9\end{array}$} & \multirow{2}{*}{$\begin{array}{c}26-50 \text { USD } \\
7\end{array}$} & \multirow{2}{*}{$\frac{51-75 \text { USD }}{1}$} & \multirow{2}{*}{$\frac{76-100 \text { USD }}{1}$} & \multirow{2}{*}{$\frac{\text { Ponad } 100 \text { USD }}{1}$} & \multirow{2}{*}{$\frac{\text { Ogółem }}{25}$} \\
\hline & $\mathrm{N}$ & 6 & & & & & & \\
\hline & $\%$ & 24 & 36 & 28 & 4 & 4 & 4 & 100 \\
\hline \multirow{3}{*}{$\begin{array}{l}\text { Rodzaj } \\
\text { wydatków }\end{array}$} & \multicolumn{2}{|c|}{ Wyżywienie } & Transport & $\begin{array}{c}\text { Prezenty } \\
\text { i inne zakupy }\end{array}$ & Zakwaterowanie & Żadne & $\begin{array}{c}\text { Opłaty } \\
\text { za imprezy }\end{array}$ & Ogółem \\
\hline & $\mathrm{N}$ & 15 & 5 & 7 & 0 & 6 & 1 & 34 \\
\hline & $\%$ & 44 & 15 & 21 & 0 & 18 & 3 & 100 \\
\hline \multirow{3}{*}{ Współuczestnicy } & \multicolumn{2}{|c|}{$\begin{array}{c}\text { Inni } \\
\text { couchsurferzy }\end{array}$} & $\begin{array}{c}\text { Bliscy } \\
\text { przyjaciele }\end{array}$ & $\begin{array}{l}\text { Członkowie } \\
\text { rodziny }\end{array}$ & Partner & $\begin{array}{c}\text { Wirtualni } \\
\text { znajomi }\end{array}$ & Brak & Ogółem \\
\hline & $\mathrm{N}$ & 7 & 4 & 2 & 6 & 3 & 5 & 27 \\
\hline & $\%$ & 25,93 & 14,81 & 7,41 & 22,22 & 11,11 & 18,52 & 100 \\
\hline \multirow{3}{*}{$\begin{array}{l}\text { Liczba } \\
\text { wyjazdów CS }\end{array}$} & \multicolumn{2}{|c|}{ Jeden } & Dwa & Trzy & Cztery & 5-10 & Ponad 10 & Ogółem \\
\hline & $\mathrm{N}$ & 5 & 3 & 2 & 2 & 2 & 11 & 25 \\
\hline & $\%$ & 20 & 12 & 8 & 8 & 8 & 44 & 100 \\
\hline \multirow{3}{*}{$\begin{array}{l}\text { Średnia długość } \\
\text { pobytu }\end{array}$} & \multicolumn{2}{|c|}{ Jedna noc } & $\begin{array}{c}\text { Dwie-trzy } \\
\text { noce }\end{array}$ & $\begin{array}{l}\text { Cztery-pięć } \\
\text { nocy }\end{array}$ & $\begin{array}{c}\text { Sześć-siedem } \\
\text { nocy }\end{array}$ & $\begin{array}{l}\text { Ponad } \\
\text { tydzień }\end{array}$ & $\begin{array}{c}\text { Ponad } \\
\text { dwa tygodnie }\end{array}$ & Ogółem \\
\hline & $\mathrm{N}$ & 5 & 4 & 6 & 7 & 2 & 1 & 25 \\
\hline & $\%$ & 20 & 8 & 12 & 14 & 4 & 2 & 100 \\
\hline
\end{tabular}

Źródło: opracowanie własne. 
Tabela 3. Opinie uczestników na temat ich doświadczeń

\begin{tabular}{|c|c|c|c|c|c|c|c|}
\hline \multicolumn{4}{|c|}{ Zadowolony } & Brak zdania & \multicolumn{3}{|c|}{ Niezadowolony } \\
\hline \multirow{3}{*}{$\begin{array}{l}\text { Zadowolenie } \\
\mathrm{z} \text { hostingu }\end{array}$} & \multicolumn{2}{|c|}{ W pełni zadowolony } & Zadowolony & Brak zdania & Niezadowolony & $\begin{array}{c}\text { Całkowicie } \\
\text { niezadowolony }\end{array}$ & Ogółem \\
\hline & $\mathrm{N}$ & 22 & 2 & 1 & 0 & 0 & 25 \\
\hline & $\%$ & 88 & 8 & 4 & 0 & 0 & 100 \\
\hline \multirow{3}{*}{$\begin{array}{l}\text { Zadowolenie } \\
\text { z couchsurfingu }\end{array}$} & \multicolumn{2}{|c|}{ W pełni zadowolony } & Zadowolony & Brak zdania & Niezadowolony & $\begin{array}{c}\text { Całkowicie } \\
\text { niezadowolony }\end{array}$ & Ogółem \\
\hline & $\mathrm{N}$ & 23 & 0 & 1 & 1 & 0 & 25 \\
\hline & $\%$ & 92 & 0 & 4 & 4 & 0 & 100 \\
\hline \multirow{3}{*}{$\begin{array}{l}\text { Wpływ CS } \\
\text { na nawiázywanie } \\
\text { kontaktów społecznych }\end{array}$} & \multicolumn{2}{|c|}{ Absolutnie tak } & Tak & Brak zdania & Nie & Absolutnie nie & Ogółem \\
\hline & $\mathrm{N}$ & 23 & 0 & 0 & 2 & 0 & 25 \\
\hline & $\%$ & 92 & 0 & 0 & 8 & 0 & 100 \\
\hline \multirow{3}{*}{$\begin{array}{l}\text { Zamiar } \\
\text { ponownego } \\
\text { udziału w CS }\end{array}$} & \multicolumn{2}{|c|}{ Absolutnie tak } & Tak & Brak zdania & Nie & Absolutnie nie & Ogółem \\
\hline & $\mathrm{N}$ & 23 & 1 & 1 & 0 & 0 & 25 \\
\hline & & 88 & 8 & 4 & 0 & 0 & 100 \\
\hline
\end{tabular}

Źródło: opracowanie własne.

Tabela 4. Kody fenomenologiczne czynników motywujących uczestników wakacji CS

\begin{tabular}{|c|c|c|c|c|c|c|c|c|c|c|c|c|c|c|c|c|c|c|c|c|c|c|c|c|c|c|}
\hline $\begin{array}{l}\overrightarrow{8} \\
\dot{8}\end{array}$ & $0^{0}$ & Z & $\bar{v}$ & ปู & $\tilde{\tilde{U}}$ & Wु & 号 & Ů & 仓े & $\infty$ & ڤે & $\begin{array}{l}0 \\
\vec{\pi} \\
\tilde{J}\end{array}$ & $\overrightarrow{\vec{n}}$ & $\begin{array}{l}\mathcal{D} \\
\tilde{U} \\
\mathcal{U}\end{array}$ & \begin{tabular}{l|}
$m$ \\
$\tilde{n}$ \\
$\tilde{U}$
\end{tabular} & $\begin{array}{l}+ \\
\tilde{J} \\
\tilde{U}\end{array}$ & $\begin{array}{l}n \\
\tilde{n} \\
\tilde{U}\end{array}$ & $\begin{array}{l}0 \\
\tilde{n} \\
\tilde{J}\end{array}$ & $\begin{array}{ll}\Delta \\
\tilde{U} \\
\tilde{J}\end{array}$ & 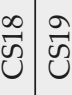 & 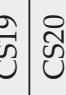 & $\begin{array}{l}\overrightarrow{\tilde{J}} \\
\tilde{\mho}\end{array}$ & 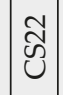 & $\tilde{\widetilde{U}}$ & 芯 & $\begin{array}{l}\stackrel{\llcorner}{2} \\
\tilde{U}\end{array}$ \\
\hline $\begin{array}{l}\text { Hobby, doświadczenie } \\
\text { duchowe, powrót } \\
\text { do zdrowia, rekreacja }\end{array}$ & 2,59 & 3 & & $x$ & & & & & & $x$ & & & & & & & & & & & & $x$ & & & & \\
\hline \begin{tabular}{|l|} 
Nowi ludzie, \\
życie towarzyskie
\end{tabular} & 21,55 & 25 & $x$ & $x$ & $x$ & $x$ & $x$ & $x$ & $x$ & $x$ & $x$ & $x$ & $x$ & $x$ & $x$ & $x$ & $x$ & $x$ & \begin{tabular}{|l|l}
$x$ & $x$ \\
\end{tabular} & \begin{tabular}{l|l}
$x$ & $x$
\end{tabular} & \begin{tabular}{l|l}
$x$ & $x$
\end{tabular} & $x$ & $x$ & $x$ & $x$ & $x$ \\
\hline $\begin{array}{l}\text { Poznawanie nowych } \\
\text { kultur i interakcje } \\
\text { międzykulturowe }\end{array}$ & 21,55 & 25 & $x$ & $\mathrm{x}$ & $x$ & $x$ & $x$ & $x$ & $x$ & $x$ & $x$ & $x$ & $x$ & $x$ & $x$ & $x$ & $x$ & $\mathrm{x}$ & \begin{tabular}{|l|l}
$x$ & $x$ \\
\end{tabular} & \begin{tabular}{l|l}
$x$ & $x$
\end{tabular} & \begin{tabular}{l|l}
$x$ & $x$
\end{tabular} & $x$ & $x$ & $x$ & $x$ & $x$ \\
\hline $\begin{array}{l}\text { Chęć podróżowania } \\
\text { do nowych destynacji, } \\
\text { miast lub krajów }\end{array}$ & 21,55 & 25 & $x$ & $x$ & $x$ & $x$ & $x$ & $x$ & $x$ & $x$ & $x$ & $x$ & $x$ & $x$ & $x$ & $x$ & $x$ & $\mathrm{x}$ & \begin{tabular}{|l|l}
$x$ & $x$ \\
\end{tabular} & \begin{tabular}{l|l}
$x$ & $x$
\end{tabular} & \begin{tabular}{l|l}
$x$ & $x$
\end{tabular} & $x$ & $x$ & $x$ & $x$ & $x$ \\
\hline $\begin{array}{l}\text { Pragnienie przeżywania } \\
\text { dobrych chwil } \\
\text { i gromadzenia pięknych } \\
\text { wspomnień }\end{array}$ & 3,45 & 4 & & $x$ & & & & $x$ & & & & & & & & & $x$ & & & & & & $x$ & & & \\
\hline $\begin{array}{l}\text { Chęć przeżycia } \\
\text { przygody i zdobycia } \\
\text { nowych doświadczen }\end{array}$ & 5,17 & 6 & & $x$ & & & $x$ & & & $x$ & & & & & & $x$ & & & & $x$ & $x$ & $x$ & & & & \\
\hline $\begin{array}{l}\text { Chęć ćwiczenia języka } \\
\text { obcego i nauki nowych }\end{array}$ & 2,59 & 3 & & $x$ & & & & & & & & & & & & & & & & & & & $x$ & & & $x$ \\
\hline Bezpieczna turystyka & 2,59 & 3 & & $\mathrm{x}$ & & & & & & $\mathrm{x}$ & & & & & & & & & & $x$ & $x$ & & & & & \\
\hline $\begin{array}{l}\text { Darmowe lub tanie } \\
\text { wakacje, oszczędność } \\
\text { pieniędzy }\end{array}$ & 2,59 & 3 & & $x$ & & & & & & $x$ & & & & & & $x$ & & & & & & & & & & \\
\hline $\begin{array}{l}\text { Pragnienie poznania } \\
\text { przyjaciół CS }\end{array}$ & 5,17 & 6 & & $x$ & & $x$ & & & & $x$ & & & & & & $x$ & & & & $x$ & & $x$ & & & & \\
\hline Nowe smaki & 1,72 & 2 & & & & & & & & & & & & & $x$ & & & & & & & & & & & $x$ \\
\hline \begin{tabular}{|l|}
$\begin{array}{l}\text { Darmowe i wygodne } \\
\text { zakwaterowanie }\end{array}$ \\
\end{tabular} & 2,59 & 3 & & $x$ & & & & & & $x$ & & & & & & & & & & & & $x$ & & & & \\
\hline $\begin{array}{l}\text { Doświadczanie } \\
\text { wspólnych emocji }\end{array}$ & 2,59 & 3 & & & & & & & & $x$ & & & & & & & & & & $x$ & & & & & $x$ & \\
\hline Zakupy i prezenty & 1,72 & 2 & & & & $\mathrm{x}$ & & & & & & & & & & & & & & $x$ & $x$ & & & & & \\
\hline $\begin{array}{l}\text { Domowe } \\
\text { zakwaterowanie }\end{array}$ & 2,59 & 3 & & $x$ & & & & & & $x$ & & & & & & & & & & & & $\mathrm{x}$ & & & & \\
\hline
\end{tabular}

Źródło: opracowanie własne. 
i związanych z hobby, kontakty towarzyskie, interakcja kulturowa i zwiedzanie nowych miejsc, tworzenie wspomnień, przeżywanie przygód i nowe doświadczenia, nauka języka, bezpieczna turystyka, darmowe lub tanie wakacje, zawieranie przyjaźni CS, poznawanie nowych smaków, bezpłatne i wygodne zakwaterowanie, doświadczanie wspólnych emocji, zakupy i zakwaterowanie w warunkach domowych.

Wśród czynników motywujących do wakacji w formie couchsurfingu najwyżej uplasowały się: „poznawanie nowych ludzi i życie towarzyskie”, "poznawanie nowych kultur poprzez interakcje kulturowe" oraz "podróżowanie do nowych destynacji" (po 21,55\%, $n=25$ ). Zostały one wskazane przez wszystkich uczestników. Niektóre opinie zaprezentowano w dalszej części tekstu:

CS2: „Jestem fotografem. Podróżowanie i robienie zdjęć $\mathrm{w}$ różnych miejscach na świecie, zbieranie wspomnień pociaga mnie, a couchsurfing jest dobrym sposobem, by to robić. Uwielbiam również przygody i poznawanie nowych miast, krajów, ludzi, kultur! Bardzo fajnie jest spotykać surferów podróżujących po różnych krajach, by przeżywać miłe chwile i ćwiczyć język. I to za darmo! I jest to tańsze niż hotel, jak sądzę".

CS8: „To lepsze niż wynajmowanie pokoju w hotelu, czuję się bezpieczny i bardziej zrelaksowany, gdy przebywam z couchsurferami. Poznawanie nowych ludzi, którzy też uwielbiają podróżować, pozwala mi odnaleźć samego siebie. Zwiedzać nowe kraje, rozwijać kontakty towarzyskie, oszczędzać pieniądze i spotykać pokrewne dusze".

CS14: „Zawsze chciałem mieć przyjaciół innej narodowości i podróżować po całym świecie, a CS mi to umożliwia. Spotykam wielu ludzi, zawieram przyjaźnie, zdobywam wspaniałe doświadczenia, poznaję inne kultury, próbuję różnego rodzaju jedzenia. Lubię podróżować po świecie, ale czasem bywa to kosztowne, więc CS to dobry pomysł, żeby ograniczyć wydatki i oszczędzić pieniądze".

CS19: „To bardzo łatwy sposób na to, by włączyć się w inną kulturę. Wspólne odczuwanie w ramach CS pociąga mnie najbardziej. Interakcja z miejscowymi, wymiana kultury, wiedzy i doświadczenia. To inny sposób podróżowania i to miłe uczucie, gdy się ma przyjaciół różnych narodowości".

CS21: „Poznaję nowy kraj i przyjaciół, których nie znałem w realu. Spotykam ludzi i poszukuję braku komfortu. Wchodzę w interakcję z przedstawicielami innej kultury. Doświadczałem innej kultury, gdy przebywałem z moim przyjacielem z platformy CS. Przebywanie w jego domu nic nie kosztuje, a wiadomo, że domy zawsze są lepsze niż hotele. Podróżuję i poznaję nowe rzeczy. Kocham podróżować i to niesamowite przeżycie, gdy człowiek dobrze się bawi i znajduje nowych przyjaciół".

W tabeli 5 zamieszczono kody fenomenologiczne dotyczące uprzedzeń uczestników wakacji CS i postrzegania przez te osoby ryzyka. Wymienione kody odnoszą się do niepostrzegania ryzyka, uprzedzeń i problematycznych doświadczeń. Spośród uczestników $60 \%$ (n=15; ranga 1$)$ nie odczuwało ryzyka ani uprzedzeń przed podróżą typu CS, natomiast 20\% $(n=5)$ stanowili ci, którzy je odczuwali przed pierwszymi doświadczeniami CS, ale nie mieli żadnych problemów podczas podróży. Udział uczestników CS, którzy doświadczyli pewnych problemów, wynosił 20\% (n=5): trzy osoby doświadczyły problemów z higiena, jedna molestowania seksualnego oraz jedna kradzieży.

Chociaż większość nie miała uprzedzeń ani poczucia ryzyka, 40\% ( $n=10)$ niepokoiło się o pewne sprawy. Obawy połowy osób wydają się słuszne. Oto opinie kilku uczestników CS, którzy byli uprzedzeni przed swoim pierwszym doświadczeniem CS, ale nie napotkali żadnych problemów:

CS3: „Najpierw się obawiałem, ale potem się przyzwyczaiłem, wiedziałem, jak to ogarnąć, nie byłem pewien, jak i czy to działa, dopóki nie dołączyłem. To dla mnie bezpieczna platforma od wielu lat".

CS8: „Nie można ufać nowym ludziom i nowym miejscom. Zawsze korzystam z CS z tą samą osobą i mam już doświadczenie w couchsurfingu, więc nie dostrzegam żadnego ryzyka".

CS14: „Nie widziałem żadnego ryzyka, ale wiesz... nowe miejsce, nowa kultura, ty jesteś świeżą krwią...

Tabela 5. Kody fenomenologiczne dotyczące uprzedzeń na temat couchsurfingu oraz postrzegania ryzyka wśród uczestników

\begin{tabular}{|c|c|c|}
\hline Kody & $\mathrm{N}$ & $\%$ \\
\hline Nigdy nie odczułem żadnego ryzyka ani uprzedzeń & 15 & 60 \\
\hline $\begin{array}{l}\text { Nigdy nie doświadczyłem żadnych problemów, ale miałem uprzedzenia / poczucie ryzyka przed moim } \\
\text { pierwszym doświadczeniem CS }\end{array}$ & 5 & 20 \\
\hline Doświadczyłem następujących problemów: & 5 & 20 \\
\hline Doświadczyłem problemów z higieną & 3 & 12 \\
\hline Byłam narażony na molestowanie seksualne & 1 & 4 \\
\hline Doświadczyłem kradzieży & 1 & 4 \\
\hline Ogółem & 25 & 100 \\
\hline
\end{tabular}

Źródło: opracowanie własne. 
To było ryzykowne za pierwszym razem. Wolę jeździć z osoba, którą znam, więc nie przychodzą mi już do głowy żadne ponure myśli".

CS21: „Mogłem mieć wypadek i moja rodzina mogła nie wiedzieć, gdzie mnie szukać. Trochę się denerwowałem, przemierzając nocą ulice nowego, dalekiego i obcego miasta".

CS23: „Przed moim pierwszym couchsurfingiem trochę się bałem, bo nie znałem wcześniej tych ludzi w realu".

CS24: „Tak, bo ta osoba była bardzo dobrym przyjacielem, ale tak jak mówiłam, znałam go tylko z mediów społecznościowych, wszyscy byli do tego uprzedzeni, ale jak już przywykłam, uprzedzenie minęło".
Niektórzy uczestnicy napotkali takie problemy, jak: nieodpowiednia higiena, molestowanie seksualne i kradzież. Oto niektóre opinie na ten temat:

Problemy z higieną:

CS6: „Trochę ta higiena... Nie chcę oceniać ludzi według ich dbałości o higienę, ale dla mnie miejsce, w którym przebywałem, nie było wystarczająco czyste".

CS9: „Tak, ten dom, w którym mieszkaliśmy, nie był higieniczny".

CS11: „Nie bardzo, pod względem bezpieczeństwa i higieny".

\section{Ryzyko molestowania seksualnego:}

CS5: „Uważam, że czasem faceci myśla, że CS to nowy Tinder".

Tabela 6. Kody fenomenologiczne opinii uczestników na temat interakcji kulturowej, turystyki kulturalnej i rozwijania kontaktów towarzyskich w ramach CS

\begin{tabular}{|c|c|c|c|c|c|c|c|c|c|c|c|c|c|c|c|c|c|c|c|c|c|c|c|c|c|c|c|}
\hline $\begin{array}{l}\vec{\theta} \\
\stackrel{0}{1}\end{array}$ & Z & $\circ^{\circ}$ & $\bar{w}$ & Uె & $\tilde{m}^{\infty}$ & Uే & un & $\stackrel{\bullet}{\cup}$ & $\hat{\omega}$ & $\begin{array}{l}\infty \\
0 \\
\cup\end{array}$ & $\begin{array}{l}\sigma \\
\tilde{u}\end{array}$ & 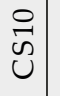 & $\overrightarrow{\tilde{u}}$ & $\stackrel{\mathcal{Z}}{\mathcal{S}}$ & $\stackrel{m}{\omega}$ & $\begin{array}{l}\Delta \\
\tilde{A} \\
\mathcal{U}\end{array}$ & $\begin{array}{l}10 \\
\tilde{D} \\
0\end{array}$ & $\mid \begin{array}{l}0 \\
w \\
u \\
u\end{array}$ & $\vec{u}$ & $\begin{array}{l}\infty \\
\vec{u} \\
u\end{array}$ & $\begin{array}{l}\stackrel{a}{u} \\
\tilde{u}\end{array}$ & $\begin{array}{l}\stackrel{1}{ } \\
\text { U } \\
\text { | }\end{array}$ & $\begin{array}{l}\vec{N} \\
\tilde{U}\end{array}$ & $\begin{array}{l}\text { ปิ } \\
\text { บี }\end{array}$ & $\begin{array}{l}\tilde{N} \\
\mathcal{U} \\
\mathcal{U}\end{array}$ & $\begin{array}{l}\mathbb{N} \\
\tilde{U} \\
\cup\end{array}$ & $\begin{array}{l}\stackrel{2}{N} \\
\text { U }\end{array}$ \\
\hline $\begin{array}{l}\text { Uczenie się nowych } \\
\text { kultur i synteza } \\
\text { kulturowa }\end{array}$ & 13 & 13,13 & $x$ & $x$ & $x$ & & $x$ & & & $x$ & & $x$ & & $x$ & $x$ & & & $x$ & & $x$ & & $\mathrm{x}$ & $x$ & & $x$ & & \\
\hline $\begin{array}{l}\text { Posiadanie przyjaciół } \\
\text { z innych kultur }\end{array}$ & 12 & 12,12 & $x$ & & $x$ & $x$ & & & $x$ & & $\mathrm{x}$ & & $x$ & & $\mathrm{x}$ & & $\mathrm{x}$ & & $\mathrm{x}$ & & & $x$ & & $x$ & & $x$ & \\
\hline $\begin{array}{l}\text { Poznawanie nowych } \\
\text { ludzi z innego kręgu } \\
\text { kulturowego }\end{array}$ & 10 & 10,10 & $x$ & $\mathrm{x}$ & & & & $\mathrm{x}$ & $\mathrm{x}$ & & & $\mathrm{x}$ & & $\mathrm{x}$ & & $x$ & & $x$ & & & $\mathrm{x}$ & & $x$ & & & & \\
\hline $\begin{array}{l}\text { Odkrywanie nowych } \\
\text { rzeczy }\end{array}$ & 5 & 5,05 & & & $x$ & & & & & $x$ & $x$ & & & & & & $x$ & & & & & & & & & & $x$ \\
\hline $\begin{array}{l}\text { Poszerzanie } \\
\text { horyzontów } \\
\text { i otwarcie umysłu }\end{array}$ & 14 & 14,14 & $x$ & $\mathrm{x}$ & $\mathrm{x}$ & & $x$ & $\mathrm{x}$ & & $x$ & & & $x$ & & & $x$ & & & $\mathrm{x}$ & & $\mathrm{x}$ & & $x$ & $x$ & & $x$ & $x$ \\
\hline $\begin{array}{l}\text { Nowe doświadczenia } \\
\text { (jedzenie, podróże, } \\
\text { zwiedzanie) }\end{array}$ & 8 & 8,08 & $x$ & $x$ & $x$ & & & & $x$ & & $x$ & & & & $x$ & & & & & $x$ & & & & & & & $x$ \\
\hline $\begin{array}{l}\text { Doświadczanie } \\
\text { kultury miejsca } \\
\text { w jej naturalnym } \\
\text { środowisku }\end{array}$ & 5 & 5,05 & & $x$ & & & & & & & & $x$ & & & & & & $x$ & & & & & & & $x$ & $x$ & \\
\hline Nauka innego języka & 5 & 5,05 & & & $x$ & & $\mathrm{x}$ & & & & & & & $\mathrm{x}$ & & & & & & & $x$ & & & $x$ & & & \\
\hline Realizacja marzeń & 6 & 6,06 & & & $x$ & & & $\mathrm{x}$ & & & & & $x$ & & & & $\mathrm{x}$ & & $x$ & & & $\mathrm{x}$ & & & & & \\
\hline $\begin{array}{l}\text { Wkład w turystykę } \\
\text { kulturalną }\end{array}$ & 5 & 5,05 & & & $x$ & & & & $\mathrm{x}$ & & & $\mathrm{x}$ & & & & $x$ & & & & & $\mathrm{x}$ & & & & & & \\
\hline $\begin{array}{l}\text { Uczenie się bycia } \\
\text { antyrasistowskim, } \\
\text { tolerancyjnym, } \\
\text { pomocnym, } \\
\text { spokojnym } \\
\text { i gościnnym }\end{array}$ & 6 & 6,06 & & & & $x$ & & & & $x$ & $x$ & & & & & & & $x$ & $x$ & & & & $x$ & & & & \\
\hline $\begin{array}{l}\text { Podniesienie } \\
\text { umiejętności } \\
\text { komunikacyjnych }\end{array}$ & 5 & 5,05 & & & & $x$ & & & & & & & & & $x$ & & $x$ & & & & $x$ & & & & $x$ & & \\
\hline $\begin{array}{l}\text { Bycie bardziej } \\
\text { towarzyskim }\end{array}$ & 5 & 5,05 & $x$ & & $x$ & $x$ & $x$ & $x$ & & & & & & & & & & & & & & & & & & & \\
\hline Ogółem & 99 & 100,00 & 6 & 5 & 9 & 4 & 4 & 4 & 4 & 4 & 4 & 4 & 3 & 3 & 4 & 3 & 4 & 4 & 4 & 2 & 5 & 3 & 4 & 3 & 3 & 3 & 3 \\
\hline
\end{tabular}

Źródło: opracowanie własne. 
CS7: „Tak... zwłaszcza niektórzy faceci mogą być zboczeni. Nawet to, jak na ciebie patrza, jest molestowaniem".

CS8: „Tak, facet czasem próbuje zmusić mnie do wypicia drinka, a któregoś dnia jeden z naszej aplikacji couchsurfingowej zrobił coś seksualnego, co nazwałabym nawet dziwacznym, ale nic złego się nie stało, ponieważ odeszłam".

CS9: „,Tak, jako kobiety ryzykujemy spotkanie ze strasznymi ludźmi z traumą. Ludzie potrafią być czasem dziwni i niebezpieczni".

Ryzyko kradzieży:

CS24: „Ryzyko kradzieży, mogę chyba powiedzieć, że tak. Myślę, że drożej mi sprzedali rzeczy w sklepie z pamiątkami. Zostałam obrabowana podczas wakacji i były problemy z transportem".

Kody fenomenologiczne opinii uczestników na temat wpływu czynności CS na interakcję kulturowa, turystykę kulturalną i rozwijanie kontaktów towarzyskich zostały podane $\mathrm{w}$ tabeli 6 . W tym kontekście opisano 13 kodów: odkrywanie nowych kultur poprzez syntezę kulturową; nawiązywanie przyjaźni z przedstawicielami innych kultur; poznawanie osób z innych kręgów kulturowych; odkrywanie nowych rzeczy; poszerzanie horyzontów i wiedzy; nabywanie nowych doświadczeń (gastronomia, podróże itp.); doświadczanie kultury miejsca docelowego w jego środowisku naturalnym; uczenie się innych języków; realizacja marzeń; wkład w turystykę kulturalną; bycie pomocnym i gościnnym, dzielenie się z innymi, prezentowanie postawy antyrasistowskiej; podnoszenie umiejętności komunikacyjnych oraz bycie bardziej towarzyskim. Do najefektywniejszych elementów należą: poszerzanie horyzontów i wiedzy $(14,14 \%$; n =14), odkrywanie nowych kultur, nawiązywanie przyjaźni z przedstawicielami innych kultur $(12,12 \%$; $n=12)$ i poznawanie osób z innych kręgów kulturowych (10,10\%; $\mathrm{n}=10)$. W tej kwestii poglądy niektórych uczestników były następujące:

CS1: „Podczas podróży poznajesz różne kultury, ludzi, tradycje, więc dobrze jest, gdy masz przyjaciół z innych kultur, uczysz się o ich kulturze, a oni uczą się o twojej, to jest dobre. To bardzo korzystne dla społeczeństwa, ponieważ poszerza wiedzę o innych kulturach".

CS2: „Zobaczyłem inny kraj, poznałem nowych ludzi, spróbowałem nowych potraw... Mogę więc powiedzieć, że to pogłębiło moją wiedzę o kulturze. Jest to również wielki wkład w lokalne interakcje, które są podstawową koncepcją podróżowania. To okazja do poznawania ludzi z innych krajów o odmiennych kulturach. CS pozwala ci komunikować się z obcokrajowcami i poznawać ich kulturę".

CS3: „Fajnie jest poznawać różne kultury, języki itp. CS jest przydatny w poznawaniu nowej kultury, kulinariów danego kraju i ludzi. To może dużo dać, można mieć przyjaciela każdej narodowości".

CS21: „Mogę dowiedzieć się rzeczy o innych kulturach, jak już wspomniałam, i to jest fantastyczne, bo wcześniej nic nie wiedziałam, a teraz rozumiem wiele spraw z nimi związanych, uważam, że to jest świetne. To coś, do czego ludzie mogą dołączyć i dzielić się doświadczeniami. Tak więc niezwykle służy turystyce kulturowej. To sposób dowiadywania się o innych krajach!".

CS5: „Ma pozytywny wpływ na rozwijanie kontaktów towarzyskich. Poznałam tam nowych przyjaciół, wymieniliśmy się nawet telefonami, więc to, że masz tylu nowych przyjaciół, jest absolutnie pozytywne, w dobry sposób. CS opiera się na rozwijaniu kontaktów. Jest w stu procentach pozytywny, tworząc kanały komunikacji, pokoju i tolerancji między osobami, które mogą i chcą utrzymywać kontakty z mieszkańcami innych krajów, a nawet chcą być goszczone przez nich lub ich gościć".

W tabeli 7 zaprezentowano 11 kodów fenomenologicznych opinii dotyczących znaczenia couchsurfingu w kulturze podróżowania. Należą do nich: obniżenie wymagań odnośnie do zakwaterowania, oczekiwania niskobudżetowych wakacji, brak obsługi ze strony touroperatorów i hoteli, preferowanie drugich domów, bycie bardziej ostrożnym, koncepcja turystyki oparta na ekonomii współdzielenia, zwiększenie częstotliwości podróżowania przy wysokiej motywacji, turystyka bleisure, rosnący udział w turystyce alternatywnej (poszerzanie zakresu) oraz wakacje ze zwykłymi ludźmi pochodzącymi z innych kręgów kulturowych.

Tabela 7. Kody fenomenologiczne opinii uczestników na temat efektów CS

\begin{tabular}{|c|c|c|c|c|c|c|c|c|c|c|c|c|c|c|c|c|c|c|c|c|c|c|c|c|c|c|c|}
\hline $\begin{array}{l}\vec{\nabla} \\
\stackrel{0}{0} \\
\underline{v}\end{array}$ & Z & $\partial^{\circ}$ & $\bar{U}$ & ขै & $\mathscr{H}^{2}$ & రు & 足 & రి & $\hat{\tilde{U}}$ & 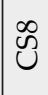 & ల్రి & 을 & $\overrightarrow{7}$ & $\frac{7}{\tilde{y}}$ & $\frac{n}{\tilde{n}}$ & $\underset{\varpi}{\tilde{U}}$ & $\stackrel{n}{\tilde{n}}$ & $\begin{array}{l}0 \\
\tilde{v}\end{array}$ & जै & $\begin{array}{l}\infty \\
\tilde{v}\end{array}$ & $\frac{\vartheta}{\tilde{v}}$ & $\begin{array}{l}\text { స్ } \\
\text { లై }\end{array}$ & స్ & $\begin{array}{l}\text { ฟิ } \\
\text { ปี }\end{array}$ & $\begin{array}{l}\tilde{7} \\
\text { ֶె }\end{array}$ & స్d & బூ \\
\hline $\begin{array}{l}\text { Obniżenie wymagań } \\
\text { odnośnie do } \\
\text { zakwaterowania }\end{array}$ & 7 & 17,95 & $x$ & $x$ & & & & $x$ & & & & $x$ & & & & & $x$ & & & & & & $x$ & & & $x$ & \\
\hline $\begin{array}{l}\text { Oczekiwania } \\
\text { niskobudżetowych } \\
\text { wakacji }\end{array}$ & 7 & 17,95 & $x$ & & & & & $x$ & $x$ & & & & $x$ & & & $x$ & & & & $x$ & $x$ & & & & & & \\
\hline $\begin{array}{l}\text { Niekorzystanie } \\
\text { z usług } \\
\text { touroperatorów } \\
\text { i hoteli }\end{array}$ & 8 & 20,51 & & $x$ & & $x$ & & $x$ & & $x$ & & & & $x$ & & & & & $x$ & & & $x$ & & & $x$ & & \\
\hline
\end{tabular}


Tabela 7 (cd.)

\begin{tabular}{|c|c|c|c|c|c|c|c|c|c|c|c|c|c|c|c|c|c|c|c|c|c|c|c|c|c|c|}
\hline $\begin{array}{l}\overrightarrow{0} \\
\stackrel{0}{*}\end{array}$ & $\mathrm{z}$ & $\therefore$ & $\bar{y}$ & ชै & $\ddot{\mathcal{U}}$ & मे & 号 & రి & $\hat{\tilde{y}}$ & $\begin{array}{l}\infty \\
U \\
ن\end{array}$ & ऊे & 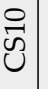 & $\overrightarrow{\tilde{n}}$ & 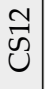 & $\stackrel{m}{\vec{U}}$ & 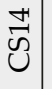 & 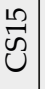 & 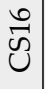 & $\widehat{\vec{\mho}}$ & $\begin{array}{l}\infty \\
\vec{U} \\
\text { | }\end{array}$ & $\overrightarrow{\vec{\nu}}$ & ฟิ & 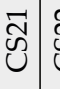 & & & ปू \\
\hline $\begin{array}{l}\text { Turystyka drugich } \\
\text { domów }\end{array}$ & 4 & 10,26 & & $\mathrm{x}$ & & & & & & & & & $\mathrm{x}$ & & & & & $\mathrm{x}$ & & & & & 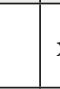 & & & \\
\hline $\begin{array}{l}\text { Bycie bardziej } \\
\text { ostrożnym/ } \\
\text { przezornym }\end{array}$ & 1 & 2,56 & & & $\mathrm{x}$ & & & & & & & & & & & & & & & & & & & & & \\
\hline $\begin{array}{l}\text { Koncepcja turystyki } \\
\text { oparta na ekonomii } \\
\text { współdzielenia }\end{array}$ & 4 & 10,26 & & $\mathrm{x}$ & & & & & & & $\mathrm{x}$ & & & & & & & & & & $\mathrm{x}$ & & & & & $\mathrm{x}$ \\
\hline $\begin{array}{l}\text { Wysoka motywacja } \\
\text { do podróży, większa } \\
\text { częstotliwość } \\
\text { podróżowania }\end{array}$ & 1 & 2,56 & & & $\mathrm{x}$ & & & & & & & & & & & & & & & & & & & & & \\
\hline $\begin{array}{l}\text { Turystyka bleisure, } \\
\text { praca na odległość }\end{array}$ & 1 & 2,56 & & & $x$ & & & & & & & & & & & & & & & & & & & & & \\
\hline $\begin{array}{l}\text { Bardziej alternatywna } \\
\text { turystyka }\end{array}$ & 2 & 5,13 & & & & & $\mathrm{x}$ & & & & & & & & $x$ & & & & & & & & & & & \\
\hline $\begin{array}{l}\text { Spędzanie wakacji } \\
\text { z różnymi ludźmi } \\
\text { z odmiennych kręgów } \\
\text { kulturowych } \\
\text { i o innych cechach } \\
\text { demograficznych }\end{array}$ & 2 & 5,13 & & & & & $\mathrm{x}$ & & & & & & & & & & & & & $\mathrm{x}$ & & & & & & \\
\hline Turystyka językowa & 2 & 5,13 & & & & & $\mathrm{x}$ & & & & & & & & & & & & & & & & $\mathrm{x}$ & & & \\
\hline Ogółem & 39 & 100,00 & 2 & 4 & 3 & 1 & 3 & 3 & 1 & 1 & 1 & 1 & 2 & 1 & 1 & 1 & 1 & 1 & 1 & 2 & 2 & 1 & 2 & \begin{tabular}{l|l}
1 & 1 \\
\end{tabular} & 1 & 1 \\
\hline
\end{tabular}

Źródło: opracowanie własne.

W tym kontekście wyraźnie zaznaczały się: rezygnacja z touroperatorów i hoteli $(20,51 \% ; n=8)$, obniżenie wymagań odnośnie do zakwaterowania $(17,95 \% ; n=7)$, oczekiwanie niskobudżetowych wakacji $(17,95 \%$; $=7)$, preferowanie prostych, niewielkich drugich domów (domy gospodarzy) $(10,26 \% ; n=4)$ oraz koncepcja turystyki oparta na ekonomii współdzielenia $(10,26 \% ; n=4)$.

W tym sensie można powiedzieć, że CS, będący nowym trendem $\mathrm{w}$ turystyce, niesie za sobą transformacje, które mogą zapoczątkować nową erę w sektorze turystycznym. Dzięki couchsurfingowi działania turystyczne mogą być podejmowane przy niższym budżecie, bez hoteli i touroperatorów, poprzez ekonomię współdzielenia i przez dodawanie nowego wymiaru drugim domom. Zastosowanie ekonomii współdzielenia i korzystanie z drugich domów można ocenić jako oszczędzanie pojemności i uznać za działanie innowacyjne. Oto opinie uczestników dotyczące tej kwestii:

CS6: „Trzeba obniżyć oczekiwania względem zakwaterowania. Jest to tańsze i bardziej atrakcyjne niż inne sposoby, a ludzie mogą sobie pomagać w ten sposób. No wiesz, inne sposoby podróżowania mogą być drogie. To jest lepsze niż biura podróży i hotele. Jest bezpłatne (w większości) i możesz podróżować lepiej niż z jakąkolwiek organizacją turystyczną".

CS3: „Musimy zadbać o siebie 10 razy bardziej i to jest trudniejsze w podróżowaniu. Wiem więcej o innych kulturach. Mam większą motywację, by podróżować po świecie. Szukam pracy z dala od domu, żebym mógł więcej podróżować w tym samym czasie, bo wielu moich gospodarzy pracowało w ten sposób".

CS5: „Zmieniłem swoją kulturę podróżowania - dzięki CS poznałem wielu obcokrajowców i poprawiłem swój angielski. Odkryłem, że młodzi ludzie są bardzo otwarci. CS poszerza moje możliwości podróżowania".

Na rysunku 1 zaprezentowano chmurę słów, które podali użytkownicy CS w swoich odpowiedziach na pytania otwarte. Algorytm chmury umieszcza centralnie najważniejsze słowa, zapisane większym stopniem pisma, a mniej ważne wyrazy - mniejszym (Voyant-tools, 2021). Na rysunku1 widać, że uczestnicy umieszczają centralnie następujące słowa: „CS", „,nowy”, ,kultura”, „ludzie”, "podróżowanie”, ,"kraje”, , ,znać”, , doświadczenie” oraz "ryzyko", zapisane dużym stopniem pisma. Wnioski nasuwające się po przyjrzeniu się chmurze wyrazowej (metoda analizy jakościowej) są zgodne z wynikami analizy treści oraz analizy kodów. Można powiedzieć, że aktywność couchsurfingowa leży u podstaw doświadczania odmiennych sytuacji, takich jak: poznawanie nowych osób, zwiedzanie nowych miejsc, odkrywanie innych kultur, podróżowanie i zdobywanie wiedzy.

Obecne wyniki pokazuja że CS może być popularnym trendem turystycznym, opartym na ekonomii współdzielenia, który skupia ludzi podróżujących. 


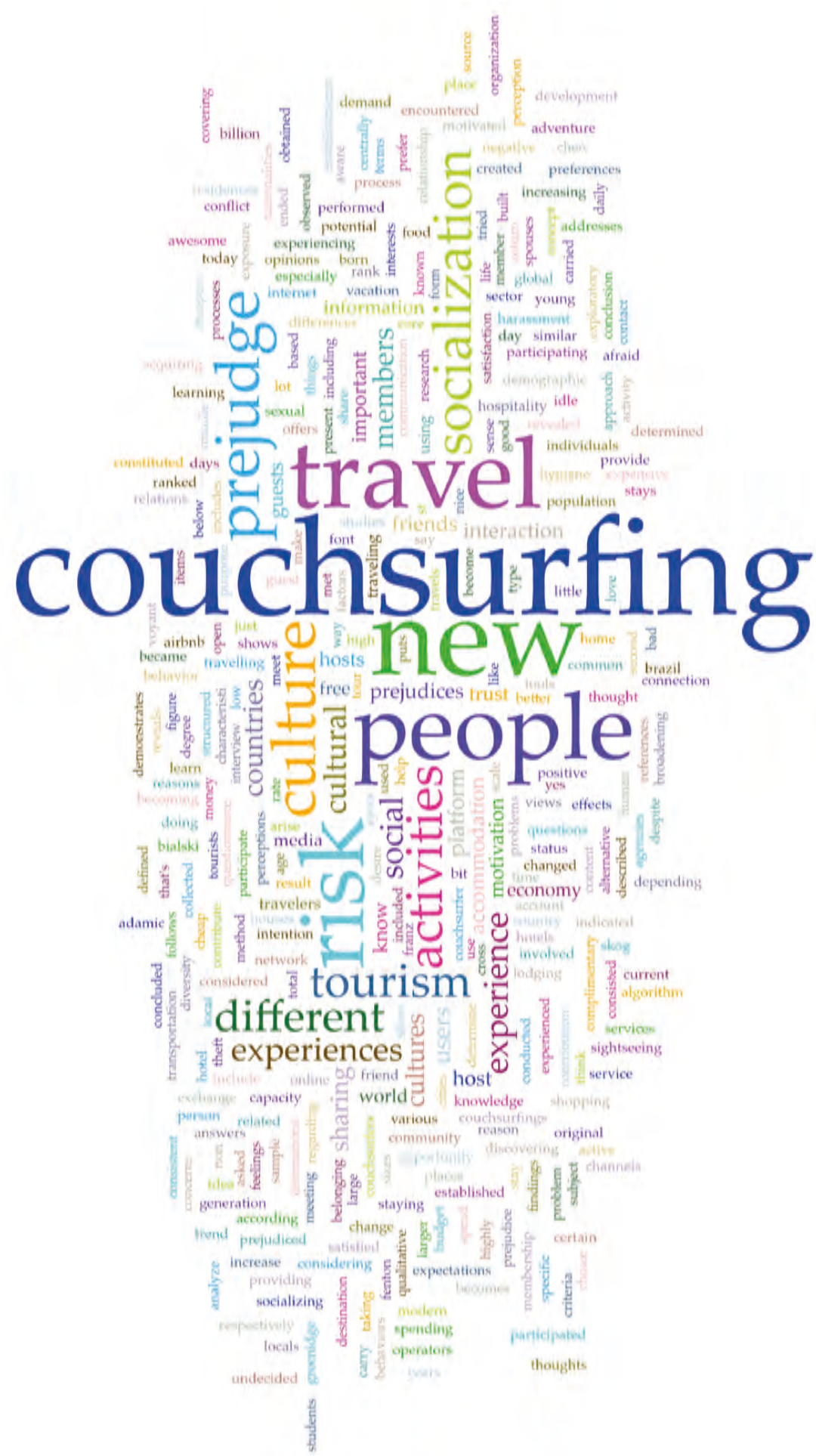

Rysunek 1. Chmura wyrazowa słów używanych przez uczestników couchsurfingu Źródło: opracowanie własne

\section{DYSKUSJA I WNIOSKI}

Badania pokazały, że najważniejszą motywacją dla couchsurferów jest innowacja. Odkryto, że pragnienie zwiedzania nowych miejsc, poznawania nowych ludzi i odkrywania innych kultur silnie motywowały uczestników. Wyniki te pokrywają się z wnioskami Ayers-Greenidge (2012).
Wprawdzie niniejsze badania wykazuja, że większość uczestników nie miała obiekcji i nie dostrzegała ryzyka, jednak ci, którzy brali udział w couchsurfingu po raz pierwszy, początkowo byli do niego uprzedzeni. Jest to zgodne z wynikami Dén-Nagy i Király'ego (2014). Jednakże stwierdzono, że niektórzy uczestnicy mający uprzedzenia faktycznie napotkali różne problemy (higiena, molestowanie seksualne, kradzież) podczas 
couchsurfingu. Mimo to większość uczestników, którzy mieli uprzedzenia przed swoim pierwszym doświadczeniem z CS, szybko je przełamała. Skog (2012) stwierdził, iż uprzedzenia niektórych uczestników z czasem się zmieniły.

Uczestnicy badania odbyli wiele podróży w formie couchsurfingu. Zasadniczo są oni zadowoleni ze swoich gospodarzy oraz zamierzają ponownie podróżować w ten sposób. Ten wynik zgadza się ze spostrzeżeniami Franz (2012). W dodatku fakt, że wielu spośród respondentów wyjeżdżało na zasadzie couchsurfingu już ponad 10 razy, jest potwierdzeniem wyników badań Chena (2018), w którego opinii couchsurfing stał się kulturą podróży. Co więcej, CS znacznie przyczynia się do kulturowej interakcji nawiązywania kontaktów pomiędzy uczestnikami. Stwierdzenie to jest również zgodne z wnioskami Skoga (2012).

Uzyskane wyniki są zbieżne z wnioskami Ayers-Greenidge (2012), ale nie z tymi przedstawionymi przez Sahbaza (2019). Może to wynikać z faktu, że osoby tworzące analizowaną przez niego próbę pochodziły z jednego kraju oraz że oceniano zupełnie inne czynniki motywacyjne. $W$ dodatku rezultaty raportowane przez Moreirę i Gomes (2018) różnią się od wyników zaprezentowanych w niniejszym artykule. Wydaje się, że wskazane przez nich czynniki skłaniające uczestników do wybory couchsurfingu nie wykazują podobieństwa do motywacji wymienionych w niniejszej pracy, co prawdopodobnie wynika z odmienności próby (tylko Brazylia).

Pultar, Raubal i Goulias (2012) przeprowadzili szeroko zakrojone badanie na 228 członkach platformy CS z 40 różnych krajów. Celem tego przedsięwzięcia było jedynie określenie demograficznych cech uczestników oraz udzielenie odpowiedzi na pytanie, czy korzystali z platformy jako goście czy jako gospodarze. Chociaż wspomniane studium - ze względu na udział respondentów z wielu różnych krajów - jest podobne do badania opisanego w niniejszym artykule, to jednak różni się od niego pod względem celu. Niemożliwe było zatem uzyskanie podobnych wyników.

Odmienne wyniki osiągnięto również w innych badaniach (Chen, 2018; Moreira, Gomes, 2018; Pultar, Raubal, Goulias, 2012; Şahbaz, 2019). Na przykład na podstawie zaprezentowanych w niniejszym artykule studiów uznano, że respondenci generalnie nie lubią brać udziału w couchsurfingu sami. Założono, że wynika to z pragnienia zmniejszenia ryzyka związanego z zakwaterowaniem. Można również stwierdzić, że uczestnicy pragną angażować się w tego typu działania z osobami, które podróżują z takich samych powodów i mają jednakowe cele.

Uczestnicy aktywności CS mają niskobudżetowe wakacje, oparte na założeniach gospodarki współdzielenia, z wyłączeniem udziału podstawowych przedsiębiorstw turystycznych, takich jak biura podróży i miejsca zakwaterowania. Jednakże poza szukaniem darmowego noclegu przez platformę uczestnicy CS wydają pieniądze na jedzenie i napoje, transport, pamiątki itp. w krajach lub miejscowościach, do których podróżują. Może to skutkować wzrostem liczby osób uczestniczących w działaniach o charakterze turystycznym przy malejących wydatkach.

Podsumowując, szeroko rozpowszechnione działania CS (rosnący trend) mogą być czynnikiem przekształcającym sektor turystyczny. Może się wydawać nieuniknione, że wszyscy interesariusze będą uważnie śledzić ten proces i dotrzymają mu kroku. W przeciwnym razie destynacje i lokale turystyczne, które nie są w stanie wykazać się elastycznością lub dostosować się do tych innowacji, mogą nie odnieść sukcesu. Współczesny marketing inspirowany klientem wywołał potrzebę zabierania głosu w kwestii konfliktu między podażą a popytem. Fenomenologiczne cytaty z wypowiedzi uczestników również stanowią poparcie zaprezentowanych wniosków. Z tych powodów dalsze badania inicjatyw podobnych do couchsurfingu, jako przykładu ekonomii współdzielenia i alternatywnego podejścia do konsumentów, zorientowanego na rozwiązania, stanowiłyby istotny wkład w literaturę przedmiotu. W związku z tym powinny być one skoncentrowane na innych współczesnych zjawiskach, takich jak: Airbnb, Eatwith czy Trip4Real.

\section{REFERENCES/BIBLIOGRAFIA}

Aktan, E. (2018). Sosyal medyanın turizm pazarlamasındaki rolünün değerlendirilmesi'. Journal of Gastronomy Studies, 6 (3), 228-248. https://doi.org/10.21325/jotags.2018.280

Anderson, C. (2012). The impact of social media on lodging performance. Ithaca: Cornell hospitality report.

Ayers-Greenidge, E. (2012). Free associations: An exploration of guests' experiences in the couchsurfing exchange. California: Wright Institute.

Başarangil, İ. (2019). Sosyal medyanın tatil tercihlerine etkisi: kırklareli üniversitesi turizm fakültesi öğrencileri üzerine bir araştırma. Journal of Tourism and Gastronomy Studies, 7 (2), 839-852.

Bialski, P. (2012). Technologies of hospitality: How planned encounters develop between strangers. Hospitality and Society, 1, 245-260. https://doi.org/10.1386/hosp.1.3.245_1

Brown, R. (2009). Public relations and the social web: How to use social media and web 2.0 in communications. New Jersey: Kogan Page Publishers.

Chen, D.-J. (2018). Couchsurfing: Performing the travel style through hospitality exchange. Tourist Studies, 18 (1), 105-122. https://doi.org/10.1177/1468797617710597

Chung, J., Buhalis, D. (2009). Virtual travel community: Bridging travellers and locals. In: N. Sharda (ed.), Tourism Informatics: Visual travel recommender systems, social communities, and user interface design (pp. 130-144). Hershey: Information Science Reference. https://doi.org/10.4018/978-1-60566-818-5.ch008 
Couchsurfing (2021). Retrieved from: https://www.couchsurfing. com (10.01.2021).

Dén-Nagy, I., Király, G. (2014). How to explain couchsurfing's success? Review of Sociology, 24 (4), 32-53.

Doyle, C. (2016). Generation Y. A dictionary of marketing. Oxford: Oxford University Press.

Franz, M. (2013). Couchsurfing: Experiences, reputation, references and decision-making in an online hospitality network. Master Thesis, University of Jyväskylä.

Güler, A., Halıcıoğlu, M.B., Taşğın, S. (2013). Sosyal bilimlerde nitel araştırma yöntemleri. Ankara: Seçkin.

Hanchuk, O., Bondarenko, O., Varfolomyeyeva, I., Pakhomova, O., Lohvynenko, T. (2020). Couchsurfing as a virtual hospitality network and a type of sustainable youth tourism. E3S Web of Conferences, 166, 09005. https://doi.org/10.1051/ e3sconf/202016609005

Huang, C.D., Goo, J., Nam, K., Yoo, C.W. (2017). Smart tourism technologies in travel planning: The role of exploration and exploitation. Information \& Management, 54 (6), 757-770. https:// doi.org/10.1016/j.im.2016.11.010

İmre, N. (2020). Turizm sektöründe sosyal medya kullanımı üzerine bir değerlendirme. Türk Turizm Araştırmaları Dergisi, 4 (2), 1655-1670. https://doi.org/10.26677/TR1010.2020.418

Kang, M., Schuett, M.A. (2013). Determinants of sharing travel experiences in social media. Journal of Travel and Tourism Marketing, 30 (1-2), 93-107. https://doi.org/10.1080/10548408.2013.751237

Lauterbach, D., Truong, H., Shah, T., Adamic, L. (2009). Surfing a web of trust: Reputation and reciprocity on couchsurfing. com. In: 2009 International Conference on Computational Science and Engineering (pp. 346-353). Vancouver: IEEE Computer Society. https://doi.org/10.1109/CSE.2009.345

Molz, J.G. (2012). Couchsurfing and network hospitality: 'It's not just about the furniture'. Hospitality \& Society, 1 (3), 215-225. https://doi.org/10.1386/hosp.1.3.215_2

Moreira, M.A.N., Gomes, C.L. (2018). The hospitality in the social network Couchsurfing: Crossing the virtual threshold in Jaguarão, in the extreme south of Brazil. Revista Brasileira Pesquisa Turismo, São Paulo, 12 (2), 1-24. https://doi.org/10.7784/ rbtur.v12i2.1399
Picard, D., Buchberger, S. (2013). Couchsurfing cosmopolitanisms can tourism make a better world. New York: Transcript-Verlag. https://doi.org/10.14361/transcript.9783839422557

Pultar, E., Raubal, M., Goulias, K. (2012). The role of geography in couchsurfing social network activities. International Conference on Geographic Information Science, Avingon.

Rosen, D., Lafontaine P.R., Hendrickson B. (2011). Couchsurfing: Belonging and trust in a globally cooperative online social network. New Media \& Society, 13 (6), 981-998. https://doi. org/10.1177/1461444810390341

Şahbaz, A. (2019). Airbnb ve Couchsurfing kullanıcılarının paylaşım ekonomisine katılım motivasyonları arasındaki farklılıklar Türkiye örneği. İstanbul Üniversitesi, Yüksek Lisans Tezi.

Schuckert, M., Peters, M., Pilz, G. (2017). The co-creation of host - guest relationships via CouchSurfing: A qualitative study. Tourism Recreation Research, 43 (2), 230-234. https://doi.org/10 .1080/02508281.2017.1384127

Skog, C. (2012). Couchsurfing - A choice for travelers. Haaga-Helia University of Applied Sciences, Bachelor's Thesis, Degree Program in Tourism, Finland.

Spitz, T. (2017). The Commodification of hospitality. An analysis of tourism encounters between interculturality and difference in regard to Turkish Couchsurfing experiences. Graduate Thesis. Kadir Has University, Graduate School of Social Sciences.

Voyant-tools (2021). Cirrus. Retrieved from: https://voyant-tools. org/docs/\#!/guide/cirrus (14.01.2021).

We are social (2021). Retrieved from: https://wearesocial.com/digital-2020 (14.01.2021)

Weber, M. (2009). Marketing to the social web: how digital customer communities build your business. Second Edition. New Jersey: John Willey and Sons Inc. https://doi.org/10.1002/9781118258125

Xiang, Z., Gretzel, U. (2010). Role of social media in online travel information search. Tourism Management, 31 (2), 179-188. https://doi.org/10.1016/j.tourman.2009.02.016

Zgolli, S., Zaiem, I. (2018). CouchSurfing: A new form of sustainable tourism and an exploratory study of its motivations and its effect on satisfaction with the stay. International Journal of Culture, Tourism and Hospitality Research, 12 (1), 130-142. https://doi.org/10.1108/IJCTHR-02-2017-0015 